\title{
Novel Interactions Involving the Mas Receptor Show Potential of the Renin-Angiotensin system in the Regulation of Microglia Activation: Altered Expression in Parkinsonism and Dyskinesia
}

\author{
Rafael Rivas-Santisteban ${ }^{1,2}$ • Jaume Lillo ${ }^{1,2}$ - Ana Muñoz ${ }^{2,3}$ • Ana I. Rodríguez-Pérez ${ }^{2,3}$ • José Luís Labandeira-García ${ }^{2,3}$. \\ Gemma Navarro $^{2,4} \cdot$ Rafael Franco $^{1}$ (I)
}

Accepted: 2 December 2020 / Published online: 20 January 2021

(C) The American Society for Experimental NeuroTherapeutics, Inc. 2021

\begin{abstract}
The renin-angiotensin system (RAS) not only plays an important role in controlling blood pressure but also participates in almost every process to maintain homeostasis in mammals. Interest has recently increased because SARS viruses use one RAS component (ACE2) as a target-cell receptor. The occurrence of RAS in the basal ganglia suggests that the system may be targeted to improve the therapy of neurodegenerative diseases. RAS-related data led to the hypothesis that RAS receptors may interact with each other. The aim of this paper was to find heteromers formed by Mas and angiotensin receptors and to address their functionality in neurons and microglia. Novel interactions were discovered by using resonance energy transfer techniques. The functionality of individual and interacting receptors was assayed by measuring levels of the second messengers cAMP and $\mathrm{Ca}^{2+}$ in transfected human embryonic kidney cells (HEK-293T) and primary cultures of striatal cells. Receptor complex expression was assayed by in situ proximity ligation assay. Functionality and expression were assayed in parallel in primary cultures of microglia treated or not with lipopolysaccharide and interferon- $\gamma$ (IFN- $\gamma)$. The proximity ligation assay was used to assess heteromer expression in parkinsonian and dyskinetic conditions. Complexes formed by Mas and the angiotensin $\mathrm{AT}_{1}$ or $\mathrm{AT}_{2}$ receptors were identified in both a heterologous expression system and in neural primary cultures. In the heterologous system, we showed that the three receptors-MasR, $\mathrm{AT}_{1} \mathrm{R}$, and $\mathrm{AT}_{2} \mathrm{R}-\mathrm{can}$ interact to form heterotrimers. The expression of receptor dimers $\left(\mathrm{AT}_{1} \mathrm{R}-\mathrm{MasR}\right.$ or $\left.\mathrm{AT}_{2} \mathrm{R}-\mathrm{MasR}\right)$ was higher in microglia than in neurons and was differentially affected upon microglial activation with lipopolysaccharide and IFN- $\gamma$. In all cases, agonist-induced signaling was reduced upon coactivation, and in some cases just by coexpression. Also, the blockade of signaling of two receptors in a complex by the action of a given (selective) receptor antagonist (cross-antagonism) was often observed. Differential expression of the complexes was observed in the striatum under parkinsonian conditions and especially in animals rendered dyskinetic by levodopa treatment. The negative modulation of calcium mobilization (mediated by $\mathrm{AT}_{1} \mathrm{R}$ activation), the multiplicity of possibilities on RAS affecting the MAPK pathway, and the disbalanced expression of heteromers in dyskinesia yield new insight into the operation of the RAS system, how it becomes unbalanced, and how a disbalanced RAS can be rebalanced. Furthermore, RAS components in activated microglia warrant attention in drug-development approaches to address neurodegeneration.
\end{abstract}

Gemma Navarro and Rafael Franco contributed equally to this work.

Rafael Franco

rfranco123@gmail.com; rfranco@ub.edu

1 Department Biochemistry and Molecular Biomedicine, School of Biology, University of Barcelona, Diagonal 643,

Barcelona, Catalonia 08028, Spain

2 Centro de Investigación en Red, Enfermedades Neurodegenerativas (CIberNed), Instituto de Salud Carlos III, Valderrebollo 5, Madrid, Madrid 28031, Spain
3 Laboratory of Cellular and Molecular Neurobiology of Parkinson's disease, Research Center for Molecular Medicine and Chronic Diseases (CIMUS), Department of Morphological Sciences, IDIS, University of Santiago de Compostela, Santiago de Compostela 15782, Spain

4 Department of Biochemistry and Physiology, School of Pharmacy and Food Science, University of Barcelona,

Barcelona, Catalonia 08028, Spain 
Key Words Parkinson $\cdot$ microglia $\cdot$ Mas receptor $\cdot$ GPCR $\cdot$ angiotensin $\cdot$ angiotensin $\mathrm{AT}_{1}$ receptor $\cdot$ angiotensin $\mathrm{AT}_{2}$ receptor

\section{Introduction}

The renin-angiotensin system (RAS) has been widely studied for its role in controlling blood pressure. Protein components of RAS are angiotensin-converting enzyme 1 (ACE1), which produces angiotensin II (Ang II); angiotensin-converting enzyme 2 (ACE2), which converts Ang II to angiotensin 1-7 (Ang(1-7)); the Ang II receptors $\mathrm{AT}_{1} \mathrm{R}$ and $\mathrm{AT}_{2} \mathrm{R}$; and the Ang(1-7) receptor Mas. For several decades, the balance between the prooxidative, proinflammatory, and the antioxidative, anti-inflammatory RAS arms was thought to be centered in the functional equilibrium of $\mathrm{AT}_{1} \mathrm{R}$ and $\mathrm{AT}_{2} \mathrm{R}$. Now, the role of the ACE2/Mas receptor function has been revealed as a crucial element of RAS balance and RAS function. The Mas receptor (MasR) was identified as a product of an oncogene and, because of its resemblance to the mitochondrial assembly gene from Saccharomyces cerevisiae, it was first known as Mas-related proto-oncogene. All RAS receptors belong to the superfamily of G protein-coupled receptors (GPCRs). A novel family of RAS-related receptors are named Mas-related GPCRs (Mrgprs); they respond to Ang (1-7) but their endogenous agonist is one of the newest members of the RAS system, alamandine [1-5]. ACE2 is considered the canonical cell surface receptor for SARS-CoV-2, the virus that causes COVID-19. In fact, ACE2 was serendipitously identified as the receptor for viruses of the SARS family [6-10].

RAS has a relevant role in controlling neurotransmission in both the central and peripheral nervous systems. Identification of Ang II receptors in neural cells of the substantia nigra and other regions within the basal ganglia has uncovered novel therapeutic approaches to address neurodegeneration in Parkinson's disease (PD) and other synucleinopathies [11-18]. For obvious reasons, we must consider the brain RAS to understand the neurological manifestations of some patients infected with SARS-CoV-2. In fact, some cases of COVID-19 have neurological symptoms as diverse as encephalitis and seizures [19-21]. In some cases, the basal ganglia have been identified as mediating virus-induced central nervous system (CNS) alterations [13, 22, 23].

Although angiotensin I has little biological activity, ACE1 converts it into Ang II, the principal RAS effector, which activates $\mathrm{AT}_{1} \mathrm{R}$ and $\mathrm{AT}_{2} \mathrm{R}$, whose actions in CNS development have been clearly delineated. However, in adults, the scenario is quite complex because $\mathrm{AT}_{1} \mathrm{R}$ and $\mathrm{AT}_{2} \mathrm{R}$ seemingly mediate opposite actions, whereas $\mathrm{AT}_{1} \mathrm{R}$ activation usually leads to production of reactive oxygen species, activation of $\mathrm{AT}_{2} \mathrm{R}$ counterbalances this noxious effect. In macrophages and microglia, $\mathrm{AT}_{1} \mathrm{R}$ is thought to contribute to inflammation, whereas $\mathrm{AT}_{2} \mathrm{R}$ attenuates inflammation and contributes to neuroprotection. These data reinforce the hypothesis that RAS balance is important in illnesses such as PD, which involves glial activation and neuroinflammation [14, 24-27]. MasR, whose endogenous agonist is Ang (1-7), adds complexity by mediating antioxidant and anti-inflammatory effects of $\mathrm{AT}_{2} \mathrm{R}[24,28]$. In summary, RAS action in a given cell or brain circuit depends on peptide production by ACE1 and ACE2 and the expression of RAS receptors. Overall, the mechanisms underlying RAS balance in healthy conditions and RAS unbalance in aging [14] or disease remain unknown.

The physiological action of GPCRs is often mediated by heteromers; that is, by complexes having more than one receptor. Consensus is that receptor heteromers are novel functional units - their properties are different from those of the individually expressed receptors [29-31]. The first reported heteromer consisted of two GPCRs with the same endogenous agonist; namely, the $\mu-\delta$ opioid receptor heteromer [32]. Further examples of heteromers formed by two receptors for the same endogenous ligand are adenosine $\mathrm{A}_{1}-\mathrm{A}_{2 \mathrm{~A}}$ and adenosine $A_{2 A}-A_{2 B}$ receptors. In these cases, the presence and/or activation of one of the receptors blunts the response arising in the partner receptor, and structural information can explain how the trans blockade may happen [33-38]. Importantly, it has been reported that $\mathrm{AT}_{1} \mathrm{R}$ and $\mathrm{AT}_{2} \mathrm{R}$ and MasR and $\mathrm{AT}_{2} \mathrm{R}$ form heteromers [39-41]. The aim of this study was to demonstrate the presence of Mas and $\mathrm{AT}_{1} / \mathrm{AT}_{2}$ receptor heterodimerization in neurons and microglia. The function of the MasR-AT $\mathrm{T}_{1} \mathrm{R} / \mathrm{AT}_{2} \mathrm{R}$ complexes in resting and activated microglia was investigated to complement our recent findings on $\mathrm{AT}_{1} \mathrm{R}-\mathrm{AT}_{2} \mathrm{R}$ heteromer function in neural cells [42]. Importantly, we assessed the expression of heteroreceptor complexes in animal models of parkinsonian and dyskinesia. We focused on the striatum because of its relevance in PD. Our results provide a holistic model to understand RAS action, especially under conditions in which microglia become activated.

\section{Materials and Methods}

\section{Reagents}

Lipopolysaccharide (LPS), interferon- $\gamma$ (IFN- $\gamma$ ), Ang II, CGP-42112A, Ang [1-7], candesartan, PD123319, and A779 were purchased from Sigma-Aldrich (St. Louis, MO, USA). Forskolin was purchased from Tocris (Bristol, UK). The concentrations of ligands used for signaling assays were selected on the basis of the dose-response experiments shown in Supplementary Figure S1. 


\section{Cell Culture}

Human embryonic kidney (HEK-293T) cells were grown in Dulbecco's modified Eagle's medium (DMEM; Gibco/ Thermo Fisher Scientific, Paisley, UK) supplemented with $2 \mathrm{mM}$ L-glutamine, $100 \mu \mathrm{g} / \mathrm{mL}$ sodium pyruvate, $100 \mathrm{U} / \mathrm{mL}$ penicillin/streptomycin, MEM Non-Essential Amino Acids Solution (1/100) and 5\% (v/v) heat-inactivated fetal bovine serum (FBS) (all supplements were from Invitrogen/Thermo Fisher Scientific, Paisley, UK). Cells were maintained at $37^{\circ} \mathrm{C}$ in a humid atmosphere of $5 \% \mathrm{CO}_{2}$.

As mentioned in the "Introduction," in this study, we focused on brain striatum. To prepare mice striatal primary microglial cultures, the brain was removed from $\mathrm{C} 57 \mathrm{BL} / 6$ mice at 2 to 4 days of age. Microglial cells were isolated as described in [43] and grown in DMEM supplemented with $2 \mathrm{mM}$ L-glutamine, $100 \mathrm{U} / \mathrm{mL}$ penicillin/streptomycin, MEM non-essential amino acids preparation (1/100), and $5 \%(v / v)$ heat-inactivated FBS. Briefly, striatum tissue was dissected, carefully stripped of its meninges, and digested with $0.25 \%$ trypsin for $20 \mathrm{~min}$ at $37^{\circ} \mathrm{C}$. Digestion was stopped by washing the tissue. A cell suspension was prepared by passing the cells through a $100-\mu \mathrm{m}$ pore mesh. Glial cells were resuspended in medium and seeded at a density of $1 \times 10^{6}$ cells $/ \mathrm{mL}$ in 6-well plates for cyclic adenylic acid (cAMP) assays, in 12well plates with coverslips for $i n$ situ proximity ligation assays (PLA), and in 96-well plates for mitogen-activated protein kinase (MAPK) experiments. Cultures were maintained at $37{ }^{\circ} \mathrm{C}$ in a humidified $5 \% \mathrm{CO}_{2}$ atmosphere, and unless otherwise stated, the medium was replaced once a week.

For neuronal primary cultures, the striatum from mouse embryos (E19) was removed and the neurons were isolated, as described by [44], and plated at a density of approximately $120,000 \mathrm{cells} / \mathrm{cm}^{2}$. The cells were grown in a neurobasal medium supplemented with $2 \mathrm{mM}$ L-glutamine, $100 \mathrm{U} / \mathrm{mL}$ penicillin/streptomycin, and 2\% (v/v) B27 supplement (Gibco) in a 6-, 12-, or 96-well plate for 19 to 21 days. Cultures were maintained at $37{ }^{\circ} \mathrm{C}$ in a humidified $5 \% \mathrm{CO}_{2}$ atmosphere, and the medium was replaced every 4 to 5 days.

Immunodetection of specific markers (NeuN for neurons and CD-11b for microglia) showed that neuronal preparations contained $>98 \%$ neurons and that microglia preparations contained at least $98 \%$ microglial cells $[45,46]$. Contamination by astrocytes was negligible; in our hands, the passage of the suspension through a syringe disrupts astroglial cells, and in addition, the culture medium used does not favor astrocyte survival (checked in every culture).

\section{PD Model Generation, Levodopa Treatment, and Dyskinesia Assessment}

All experiments were carried out in accordance with EU directives (2010/63/EU and 86/609/CEE) and were approved by the ethical committee of the University of Santiago de Compostela. Similar to the approach elsewhere described [47], our experimental design using male Wistar rats aimed to obtain four groups of animals as described below. Animals were 8 weeks old at the beginning of the experimental procedure.

Details of model generation and the protocol of drug administration and behavioral analysis, performed by a blinded investigator, are given elsewhere [48, 49]. Surgery was performed on rats anesthetized with ketamine/xylazine (1\% ketamine, $75 \mathrm{mg} / \mathrm{kg}$, and $2 \%$ xylazine, $10 \mathrm{mg} / \mathrm{kg}$ ). Lesions were produced in the right medial forebrain bundle to achieve a complete degeneration of the nigrostriatal pathway. The rats were injected with $12 \mu \mathrm{g}$ of 6-hydroxydopamine (6-OH-DA) (to provide $8 \mu \mathrm{g}$ of 6-hydroxy-DA free base; Sigma-Aldrich) in $4 \mu \mathrm{L}$ of sterile saline containing $0.2 \%$ ascorbic acid. These were considered "lesioned" animals. Injection of the vehicle led to the generation of naïve (or non-lesioned) animals.

The 6-OH-DA hemilesioned rat is considered a PD model. Amphetamine-induced rotation was tested in a bank of 8 automated rotometer bowls (Rota-count 8, Columbus Instruments, Columbus, OH, USA) by monitoring full $\left(360^{\circ}\right)$ body turns in either direction. Right and left full body turns were recorded over 90 min following an injection of Damphetamine (2.5 $\mathrm{mg} / \mathrm{kg}$ i.p.) dissolved in saline. Rats that displayed more than 6 full body turns/min ipsilateral to the lesion were included in the study (this rate would correspond to $>90 \%$ depletion of dopamine fibers in the striatum [50]).

Spontaneous use of forelimb can be measured by the cylinder test [51,52]. Rats were placed individually in a glass cylinder ( $20 \mathrm{~cm}$ in diameter) and the number of left or right forepaw contacts was scored by an observer blinded to the animals' identity and presented as left (impaired) touches as a percentage of total touches. A control animal would thus receive an unbiased score of $50 \%$, whereas the lesion usually reduces the performance of the impaired paw to less than $20 \%$ of total wall contacts.

Of the lesioned animals displaying parkinsonism-like behavior according to the above described tests (18 in total), 12 were chronically treated with L-DOPA daily for 3 weeks. A mixture of L-DOPA methyl ester $(6 \mathrm{mg} / \mathrm{kg})$ plus benserazide $(10 \mathrm{mg} / \mathrm{kg})$ was administered subcutaneously. The treatment reliably induces dyskinetic movements in some rats. As described in a previous report [47], abnormal involuntary movements were evaluated according to the rat dyskinesia scale described in detail elsewhere [48, 53-56]. The severity of each abnormal involuntary movement (AIM) subtype (limb, orolingual, and axial) was assessed using scores from 0 to $4(1=$ occasional, present $<50 \%$ of the time; $2=$ frequent, present $>$ $50 \%$ of the time; $3=$ continuous but interrupted by strong sensory stimuli; $4=$ continuous, not interrupted by strong sensory stimuli). Rats were classified as "dyskinetic" if 
they displayed a score $\geq 2$ per monitoring period on at least two AIM subtypes. Animals classified as "non-dyskinetic" exhibited either no L-DOPA-induced abnormal involuntary movements or very mild/occasional ones [57]. Animals with low scores, either non-dyskinetic or dyskinetic, were excluded. In summary, four groups of animals were obtained: [1] non-lesioned; [2] lesioned, treated with vehicle; [3] lesioned and became dyskinetic when treated with L-DOPA; and [4] lesioned and did not become dyskinetic upon L-DOPA treatment. Tyrosine hydroxylase immunostaining was performed in every animal from sections taken postmortem [18, 49]; selected animals undergoing 6-OH-DA treatment showed, in the lesioned hemisphere, $>95 \%$ nigral dopaminergic denervation. Overall, 4 animals (those with better scores) were selected in each of the following 4 groups: naïve, lesioned, lesioned/L-DOPA dyskinetic, and lesioned/L-DOPA nondyskinetic. The PLA analysis (see below) was performed in different fields of striatal sections from each of the 16 selected animals. The striatum was delimited in sections using a bright field, and images were captured within delimitation coordinates.

\section{Fusion proteins}

Human cDNAs for $\mathrm{AT}_{1}, \mathrm{AT}_{2}$, Mas, and $\sigma_{1}$ receptors cloned into pcDNA3.1 were amplified without their stop codons using sense and antisense primers harboring either BamHI and HindIII restriction sites to amplify $\mathrm{AT}_{1} \mathrm{R}$ and $\mathrm{AT}_{2} \mathrm{R}$ or with BamHI and EcoRI restriction sites to amplify Mas and $\sigma_{1}$ receptors. Amplified fragments were then subcloned to be in frame with an enhanced yellow fluorescent protein (pEYFP-N1; Clontech, Heidelberg, Germany) or a Rluc (pRluc-N1; PerkinElmer, Wellesley, MA) on the C-terminal end of the receptor to produce $\mathrm{AT}_{1} \mathrm{R}-\mathrm{YFP}, \mathrm{AT}_{1} \mathrm{R}$-Rluc, $\mathrm{AT}_{2} \mathrm{R}$-YFP, Mas-YFP, Mas-Rluc, and $\sigma_{1} \mathrm{R}$-Rluc fusion proteins.

\section{Cell Transfection}

HEK-293T cells were transiently transfected with the corresponding cDNA by means of the poly-ethylenimine (PEI; Sigma-Aldrich) method, as previously described [58]. Briefly, the corresponding cDNA diluted in $150 \mathrm{mM} \mathrm{NaCl}$ was mixed with PEI (5.5 $\mathrm{mM}$ in nitrogen residues) also prepared in $150 \mathrm{mM} \mathrm{NaCl}$ for $10 \mathrm{~min}$. The cDNA-PEI complexes were transferred to HEK-293T cells, which were incubated for $4 \mathrm{~h}$ in serum-starved medium. Then, the medium was replaced by fresh supplemented culture medium and cells were maintained at $37{ }^{\circ} \mathrm{C}$ in a humid atmosphere of $5 \% \mathrm{CO}_{2}$. Forty-eight hours after transfection, cells were washed, detached, and resuspended in the assay buffer.

\section{Immunocytochemistry}

HEK-293T cells were seeded on glass coverslips in 12-well plates. After $24 \mathrm{~h}$ of culture, cells were transfected with $\mathrm{AT}_{1} \mathrm{R}$-YFP cDNA $(1 \mu \mathrm{g})$ and Mas-Rluc cDNA $(1 \mu \mathrm{g})$ or with $\mathrm{AT}_{2} \mathrm{R}$-Rluc cDNA $(1 \mu \mathrm{g})$ and Mas-Rluc cDNA $(1 \mu \mathrm{g})$. Fortyeight hours later, cells were fixed in $4 \%$ paraformaldehyde for $15 \mathrm{~min}$ and washed twice with PBS containing $20 \mathrm{mM}$ glycine before permeabilization with PBS-glycine containing $0.2 \%$ Triton X-100 (5 min incubation). A blocking solution consisting of PBS containing $1 \%$ bovine serum albumin was added (1 h). HEK-293T cells were then labeled with a mouse anti-Rluc antibody (1/100; Millipore, Darmstadt, Germany) and subsequently treated with $\mathrm{Cy} 3$-conjugated anti-mouse (1/200; Jackson ImmunoResearch, West Grove, PA, USA; red) antibody (1 h each). The expression of Mas-YFP and $\mathrm{AT}_{2} \mathrm{R}$-YFP was detected by their YFP fluorescence. Nuclei were stained with Hoechst (1/100 from $1 \mathrm{mg} / \mathrm{mL}$ stock; Sigma-Aldrich). Samples were washed several times and mounted with 30\% Mowiol (Calbiochem, Merck, Darmstadt, Germany). Images were obtained in a Zeiss LSM 880 confocal microscope (Zeiss, Jena, Germany) with a $\times 63$ oil objective.

\section{Bioluminescence Resonance Energy Transfer Assay}

HEK-293T cells were transiently cotransfected with a constant amount of cDNA encoding Mas-Rluc $(0.75 \mu \mathrm{g})$ and with increasing amounts of cDNAs corresponding to $\mathrm{AT}_{1} \mathrm{R}-\mathrm{YFP}$ $(0.5$ to $2.5 \mu \mathrm{g})$ or $\mathrm{AT}_{2} \mathrm{R}$-YFP $(0.5$ to $3 \mu \mathrm{g})$. When indicated cDNA coding for $\mathrm{AT}_{1} \mathrm{R}$ fused to Rluc was used. For negative control, HEK-293T cells were transiently cotransfected with a constant amount of cDNA encoding $\sigma_{1}$-Rluc $(0.75 \mu \mathrm{g})$ and with increasing amounts of cDNA corresponding to $\mathrm{AT}_{2} \mathrm{R}$ YFP $(0.5$ to $3 \mu \mathrm{g})$. To control the cell number, sample protein concentration was determined using a Bradford assay kit (BioRad, Munich, Germany) using bovine serum albumin (BSA) dilutions as standards. To quantify fluorescent proteins, cells ( $20 \mu \mathrm{g}$ of total protein) were distributed in 96-well microplates (black plates with transparent bottoms) and fluorescence was read in a Fluostar Optima Fluorimeter (BMG Labtech, Offenburg, Germany) equipped with a high-energy xenon flash lamp, using a 10-nm bandwidth excitation filter at $485 \mathrm{~nm}$. For bioluminescence resonance energy transfer (BRET) measurements, the equivalent of $20 \mu \mathrm{g}$ of total protein cell suspension was distributed in 96-well white microplates with white bottoms (Corning 3600; Corning Inc., Corning, NY, USA). BRET was determined 1 min after adding coelenterazine $\mathrm{H}$ (Molecular Probes, Eugene, OR), using a Mithras LB 940 reader (DLReady, Berthold Technologies, Bad Wildbad, Germany), which allows the integration of the signals detected in the short-wavelength filter at $485 \mathrm{~nm}$ and the long-wavelength filter at $530 \mathrm{~nm}$. To quantify Mas-Rluc expression, luminescence readings were 
obtained 10 min after the addition of $5 \mu \mathrm{M}$ coelenterazine $\mathrm{H}$. MilliBRET units (mBU) are defined as follows:

$\mathrm{mBU}=\left[\frac{\lambda_{530}(\text { long }- \text { wavelength emission })}{\lambda_{485}(\text { short-wavelength emission })}-C_{\mathrm{f}}\right] \times 1000$

in which $C_{\mathrm{f}}$ corresponds to [(long-wavelength emission)/ (short-wavelength emission)] for the Rluc construct expressed alone in the same experiment.

\section{Sequential BRET-FRET Assay}

HEK-293T cells were transiently cotransfected with a constant amount of cDNA for MasR-Rluc $(0.6 \mu \mathrm{g})$ and for $\mathrm{AT}_{1} \mathrm{R}_{-G^{-}} \mathrm{GF}^{2}(1 \mu \mathrm{g})$ and increasing amounts of cDNA for $\mathrm{AT}_{2} \mathrm{R}-\mathrm{YFP}(0.5$ to $4.1 \mu \mathrm{g})$. For the negative control, HEK293 $\mathrm{T}$ cells were transiently cotransfected with a constant amount of $\sigma_{1}$ R-Rluc $(0.3 \mu \mathrm{g})$ and $\mathrm{AT}_{1} \mathrm{R}_{-} \mathrm{GFP}^{2}(1 \mu \mathrm{g})$ and increasing amounts of cDNA for $\mathrm{AT}_{2} \mathrm{R}-\mathrm{YFP}(0.5$ to $4.1 \mu \mathrm{g})$. To control the cell number, sample protein concentration was determined using a Bradford assay kit (Bio-Rad) using BSA dilutions as standards and adjusted to $0.2 \mathrm{mg} / \mathrm{mL}$. To quantify fluorescent proteins, cells ( $20 \mu \mathrm{g}$ of total protein) were distributed in 96-well microplates (black plates with transparent bottoms) and fluorescence was read in a Fluostar Optima Fluorimeter (BMG Labtech) equipped with a high-energy xenon flash lamp, using a 10-nm bandwidth excitation filter with a 485-nm excitation filter for YFP or 410-nm excitation filter for $\mathrm{GFP}^{2}$. For SRET measurements, the equivalent of $20 \mu \mathrm{g}$ of total protein cell suspension was distributed in 96-well white microplates (Corning 3600). SRET was determined $30 \mathrm{~s}$ after the addition of Deepblue C (5 $\mathrm{MM})$ (Molecular Probes), using a Mithras LB 940 reader (Berthold Technologies), which allows the integration of the signals detected in the shortwavelength filter at $400 \mathrm{~nm}$ and the long-wavelength filter at $530 \mathrm{~nm}$. To quantify MasR-Rluc or $\sigma_{1}$ R-Rluc expression, luminescence readings were obtained $10 \mathrm{~min}$ after the addition of $5 \mu \mathrm{M}$ coelenterazine $\mathrm{H}$.

\section{Assessment of Cytoplasmic Calcium Ion Levels}

HEK-293T cells were cotransfected with the cDNAs for $\mathrm{AT}_{1}$ $(1 \mu \mathrm{g})$ and/or $\mathrm{AT}_{2}(1 \mu \mathrm{g})$, and/or MasR $(1 \mu \mathrm{g})$ and/or the GCaMP6 calcium sensor $(1 \mu \mathrm{g})$ [59] by the use of PEI method, as described above. Forty-eight hours after transfection, HEK-293 T cells plated in 6-well plates (black, clearbottomed) were incubated with $\mathrm{Mg}^{2+}$-free Locke's buffer $\left(154 \mathrm{mM} \mathrm{NaCl}, 5.6 \mathrm{mM} \mathrm{KCl}, 3.6 \mathrm{mM} \mathrm{NaHCO}{ }_{3}, 2.3 \mathrm{mM}\right.$ $\mathrm{CaCl}_{2}$, $5.6 \mathrm{mM}$ glucose, $5 \mathrm{mM}$ HEPES, $10 \mu \mathrm{M}$ glycine, $\mathrm{pH}$ 7.4). Receptor antagonists were added $10 \mathrm{~min}$ before readings and receptor agonists were added a few seconds before readings. Fluorescence emission intensity of GCaMP6 was recorded at $515 \mathrm{~nm}$ upon excitation at $488 \mathrm{~nm}$ on an
EnSpire Multimode Plate Reader (PerkinElmer, Waltham, MA, USA) for $150 \mathrm{~s}$ every $5 \mathrm{~s}$ at 100 flashes per well.

\section{Determination of cAMP Level}

The analysis of cAMP levels in primary neural cells or in transfected HEK-293T was performed using the Lance ${ }^{\circledR}$ Ultra cAMP kit (PerkinElmer). Two hours before the experiment, cells were placed in serum-starved DMEM. Cells growing in the medium containing $50 \mu \mathrm{M}$ zardaverine were distributed in 384-well microplates (2000 HEK-293T cells or 4000 striatal neurons or microglial cells per well) and pretreated with the $\mathrm{AT}_{1} \mathrm{R}, \mathrm{AT}_{2} \mathrm{R}$, and MasR antagonists candesartan, PD123319, and A779, respectively, or with the vehicle at room temperature for $15 \mathrm{~min}$, and then stimulated with the $\mathrm{AT}_{1} \mathrm{R}, \mathrm{AT}_{2} \mathrm{R}$, and MasR agonists Ang II, CGP42112A, and Ang(1-7), respectively, for 15 min before adding $0.5 \mu \mathrm{M}$ forskolin or vehicle for an additional $15 \mathrm{~min}$. Homogeneous time-resolved fluorescence energy transfer (HTRF) measures were performed using the Lance ${ }^{\circledR}$ Ultra cAMP kit (PerkinElmer). Fluorescence at $665 \mathrm{~nm}$ was measured on a PHERAstar Flagship microplate reader equipped with an HTRF optical module (BMG Labtech). A standard curve for (cAMP) was obtained in each experiment.

\section{Extracellular Signal-Regulated Kinases 1/2 Phosphorylation}

To determine ERK1/2 phosphorylation, 40,000 HEK-293T cells expressing MasR and either $\mathrm{AT}_{1} \mathrm{R}$ or $\mathrm{AT}_{2} \mathrm{R}$, or 50,000 striatal neurons, or microglial primary cultures were plated in transparent Deltalab 96-well microplates. Two hours before the experiment, the medium was substituted with serumstarved DMEM. Cells were treated or not for $10 \mathrm{~min}$ with the selective antagonists $(300 \mathrm{nM}$ candesartan, $1 \mu \mathrm{M}$ PD123319, or $500 \mathrm{nM} \mathrm{A779)} \mathrm{followed} \mathrm{by} \mathrm{7-min} \mathrm{treatment}$ with the selective agonists (Ang II, CGP-42112A, or Ang(17). Cells were then washed twice with cold PBS before the addition of lysis buffer (15-min treatment). Ten microliters of each supernatant was placed in white ProxiPlate 384-well microplates, and ERK1/2 phosphorylation was determined using an AlphaScreen SureFire kit (PerkinElmer) following the instructions of the supplier and using an EnSpire Multimode Plate Reader (PerkinElmer).

\section{Dynamic Mass-Redistribution Label-Free Assays}

Cell signaling was explored using an EnSpire Multimode Plate Reader (PerkinElmer) by using label-free technology. Cellular cytoskeleton redistribution movement induced upon receptor activation was detected by illuminating the underside of the plate with polychromatic light and measured as changes in the wavelength of the reflected monochromatic light, which 
is a sensitive function of the index of refraction. The magnitude of this wavelength shift (in picometers) is directly proportional to the amount of dynamic mass-redistribution (DMR). To determine the label-free DMR signal, 10,000 HEK-293T cells cotransfected with cDNAs for $\mathrm{AT}_{1} \mathrm{R}(1 \mu \mathrm{g})$ or $\mathrm{AT}_{2} \mathrm{R}(1 \mu \mathrm{g})$ and MasR or 10,000 striatal neuronal or microglial primary cultures cells were plated on transparent 384-well fibronectin-coated microplates to obtain 70 to $80 \%$ confluent monolayers, and kept in the incubator for $24 \mathrm{~h}$. Before the assay, cells were washed twice with assay buffer (Hanks' balanced salt solution with 20 mM HEPES, pH 7.15, $0.1 \%$ dimethyl sulfoxide) and incubated in the reader for $2 \mathrm{~h}$ in $30 \mu \mathrm{L} /$ well of assay buffer at $24^{\circ} \mathrm{C}$. Then, the sensor plate was scanned and a baseline optical signature was recorded for 10 min before adding $10 \mu \mathrm{L}$ of test antagonist (candesartan, PD123319, or A779) dissolved in assay buffer, followed by the addition of $10 \mu \mathrm{L}$ of selective agonist (Ang II, CGP42112A, or Ang(1-7)) also dissolved in assay buffer. The DMR responses induced by the agonist were monitored for a minimum of $3600 \mathrm{~s}$.

\section{Proximity Ligation Assay}

Detection in natural sources of clusters formed by $\mathrm{AT}_{1}$ and Mas receptors or $\mathrm{AT}_{2}$ and Mas receptors was addressed in primary cultures of microglia or striatal neurons and in brain sections. Cells grown on glass coverslips were fixed in $4 \%$ paraformaldehyde for $15 \mathrm{~min}$, washed twice with PBS containing $20 \mathrm{mM}$ glycine to quench the aldehyde groups, permeabilized with the same buffer containing $0.05 \%$ Triton X-100 for 5 to $15 \mathrm{~min}$, and washed with PBS. After a 1-h incubation at $37{ }^{\circ} \mathrm{C}$ with the blocking solution in a preheated humidity chamber, samples were incubated overnight at $4{ }^{\circ} \mathrm{C}$ with a mixture of a rabbit monoclonal anti- $\mathrm{AT}_{1} \mathrm{R}$ antibody $(1 / 100$, ab124734, Abcam, Cambridge, UK) and a mouse monoclonal anti-MasR antibody (1/100, sc-390453, Santa Cruz Biotechnology, Santa Cruz, CA, USA) or a mixture of a rabbit monoclonal anti- $\mathrm{AT}_{2} \mathrm{R}$ antibody (1/100, ab92445, Abcam) and the mouse monoclonal anti-MasR antibody (1/100, sc390453, Santa Cruz Biotechnology). Nuclei were stained with Hoechst (1/100 from $1 \mathrm{mg} / \mathrm{mL}$ stock; Sigma-Aldrich). The antibodies were validated following the method in the technical brochure of the vendor and also by immunofluorescence in HEK-293T cells (transfected $v s$ non-transfected). Cells were further processed using PLA probes detecting primary antibodies (Duolink In Situ PLA probe anti-mouse plus and Duolink In Situ PLA probe Anti-Rabbit minus; all probes from Sigma-Aldrich) $\left(1 / 5 \mathrm{v}: \mathrm{v}\right.$ for $1 \mathrm{~h}$ at $\left.37{ }^{\circ} \mathrm{C}\right)$. Ligation and amplification were done as indicated by the supplier (SigmaAldrich), and cells were mounted using the mounting medium 30\% Mowiol (Calbiochem, Merck). To detect red dots corresponding to $\mathrm{AT}_{1}$-MasHets or $\mathrm{AT}_{2}$-MasHets, samples were observed in a Zeiss LSM 880 confocal microscope equipped with an apochromatic $63 \times$ oil-immersion objective, and 405and 561-nm laser lines. For each field of view, a stack of 2 channels (one per staining) and $3 Z$-planes with a step size of $1 \mu \mathrm{m}$ were acquired. Andy's algorithm, a specific ImageJ (National Institutes of Health, Bethesda, MD, USA) macro for reproducible and high-throughput quantification of the total PLA foci dots and total nuclei, was used for data analysis [60].

The specificity of antibodies against angiotensin receptors has been questioned, even though different laboratories have reported excellent performance of different antibodies see [58-61]. All antibodies used in this study were monoclonal; however, to check the specificity of the antibodies used, we performed experiments in HEK-293T cells, either nontransfected or expressing $A_{1} R$ or $A_{2} R$. Signal was negligible in $\mathrm{AT}_{2} \mathrm{R}$-expressing cells and non-transfected cells when the anti- $\mathrm{AT}_{1} \mathrm{R}$ antibody was used and negligible in $\mathrm{AT}_{1} \mathrm{R}$-expressing cells and non-transfected cells when the anti- $\mathrm{AT}_{2} \mathrm{R}$ antibody was used (Supplementary Figure S2). These results confirm the antibody specificity as previously reported [62].

\section{Data Analysis}

All data were obtained from at least five independent experiments and are expressed as the mean \pm standard error of the mean (SEM). GraphPad Prism 8 software (GraphPad Inc., San Diego, CA, USA) was used for data fitting and statistical analysis. One-way ANOVA and post hoc Bonferroni's test were used when comparing multiple values. When a pair of values was compared, Student's $t$ test was used. Significant differences were considered when the $p$ value was $<0.05$.

\section{Results}

\section{The Mas Receptor Physically Interacts with $\mathbf{A T}_{1}$ or $\mathbf{A T}_{2}$ Receptors}

Colocalization of MasR with $\mathrm{AT}_{1} \mathrm{R}$ or $\mathrm{AT}_{2} \mathrm{R}$ was first addressed using a heterologous expression system. Immunocytochemical assays performed in HEK-293T cells transfected with cDNAs encoding MasR fused to YFP and $\mathrm{AT}_{1}$ fused to Rluc (Fig. 1A-C) indicated a marked degree of colocalization (yellow in Fig. 1C). A lower degree of colocalization was observed after immunocytochemical assays performed in HEK-293T cells transfected with cDNAs encoding MasR fused to Rluc and $\mathrm{AT}_{2} \mathrm{R}$ fused to YFP (Fig. $1 \mathrm{D}-\mathrm{F})$. In those experiments, red fluorescence was due to a secondary Cy3-conjugated antibody, whereas green fluorescence was due to YFP (see "Materials and Methods"); colocalization can be observed by yellow in the merged image. It should be noted that the images are taken near the glass 

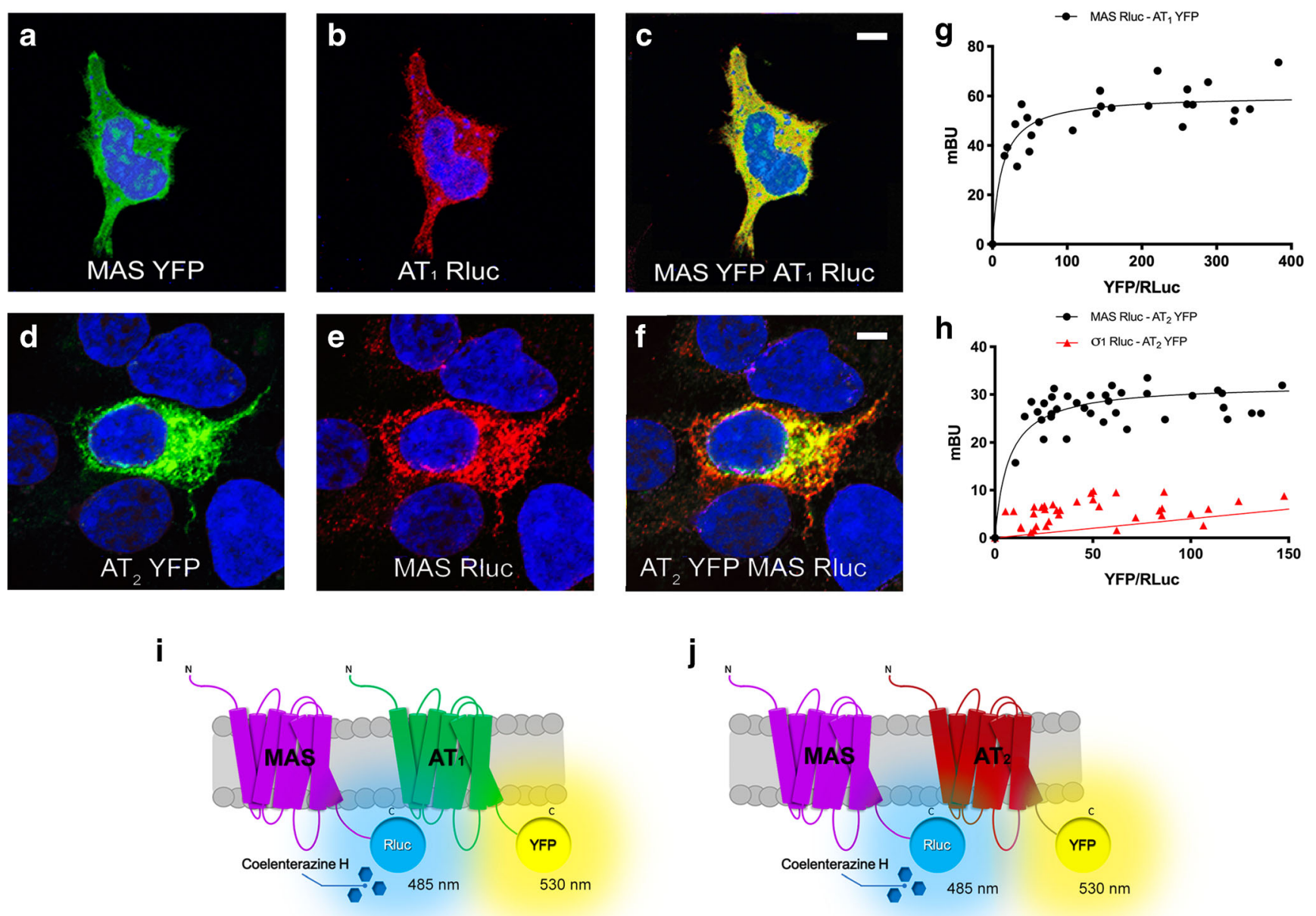

Fig. 1 Human $\mathrm{AT}_{1}$ and $\mathrm{AT}_{2}$ receptors interact with Mas receptor (MasR) in transfected HEK-293T cells. Immunocytochemistry assays were performed in HEK-293T cells expressing Mas-YFP and $\mathrm{AT}_{1}$-Rluc receptors ( $1 \mu \mathrm{g}$ of cDNA each) $(\mathbf{A}-\mathbf{C})$, or Mas-Rluc and $\mathrm{AT}_{2} \mathrm{R}-\mathrm{YFP}(1 \mu \mathrm{g}$ of cDNA each) (D-F). Images were taken using a Zeiss 880 confocal microscope. Receptors fused to YFP were detected by yellow fluorescence (green), and receptors fused to Rluc were detected by a mouse anti-Rluc antibody and a secondary Cy3 anti-mouse antibody (red). Colocalization is shown in yellow. Cell nuclei were stained with Hoechst (blue). Scale

surface, that is, most of the labeling was due to proteins in the cell membrane proximal to the slide.

Immunocytochemistry assays do not demonstrate physical interactions because they occur within distances of $200 \mathrm{~nm}$. Thus, we addressed potential interactions using BRET in HEK-293T cells expressing a constant amount of MasRRluc and increasing amounts of $\mathrm{AT}_{1} \mathrm{R}$-YFP. The saturable BRET curve (BRET max $_{\max } 60 \pm 2 \mathrm{mBU}$; BRET $_{50} 13 \pm 4 \mathrm{mBU}$ ) indicates specific interactions between Mas and $\mathrm{AT}_{1}$ receptors (Fig. 1G). A saturable curve was obtained when a similar experiment was carried out in HEK-293T cells expressing a constant amount of MasR-Rluc and increasing amounts of $\mathrm{AT}_{2} \mathrm{R}-\mathrm{YFP}\left(\mathrm{BRET}_{\max } 32 \pm 1 ; \mathrm{BRET}_{50} 7 \pm 2\right.$ ), indicating that the two receptors do physically interact in living cells (Fig. $1 \mathrm{H})$, confirming the results previously reported in HEK-293T

bar: $2 \mu \mathrm{m}$. G, H BRET assays were performed in HEK-293T cells transfected with a constant amount of cDNA for Mas-Rluc $(0.75 \mu \mathrm{g})$ or $\sigma_{1}$ R-Rluc $(0.75 \mu \mathrm{g})$ (as negative control) and increasing amounts of cDNA for $\mathrm{AT}_{1} \mathrm{R}$-YFP $(0.5$ to $2.5 \mu \mathrm{g})$ or $\mathrm{AT}_{2} \mathrm{R}$-YFP $(0.5$ to $3 \mu \mathrm{g})$. Values are the mean \pm SEM of 8 independent experiments performed in duplicates. I, J Schematic representation of BRET assays: energy transfer and fluorescence emission at $530 \mathrm{nM}$ only occurs if the BRET donor (Rluc) and the BRET acceptor (YFP) are close

cells using fluorescence resonance energy transfer and crosscorrelation spectroscopy [40]. In contrast, experiments in cells coexpressing $\sigma_{1}$ R-Rluc and $\mathrm{AT}_{2}$-YFP showed a linear nonspecific signal (negative control in Fig. 1H).

We addressed the potential formation of trimers by taking advantage of the sequential resonance energy transfer (SRET; [63]) technique using cells expressing MasR-Rluc, $\mathrm{AT}_{1} \mathrm{R}$ $\mathrm{GFP}^{2}$, and $\mathrm{AT}_{2} \mathrm{R}$-YFP. The saturable curve, which was not detected in the negative control $\left(\sigma_{1}\right.$ R-Rluc, $\mathrm{AT}_{1} \mathrm{R}-\mathrm{GFP}^{2}$, and $\mathrm{AT}_{2} \mathrm{R}-\mathrm{YFP}$ ), indicated that the three RAS receptors interacted in a heterologous system, forming trimers (Fig. 2A). Trimer formation led to a structural rearrangement; in fact, increased expression of MasR led to a higher BRET signal due to the $\mathrm{AT}_{1} \mathrm{R}-\mathrm{Rluc}$ and $\mathrm{AT}_{2} \mathrm{R}$-YFP pair. These results are consistent with the reduced distance between Rluc fused to $\mathrm{AT}_{1} \mathrm{R}$ and 
a

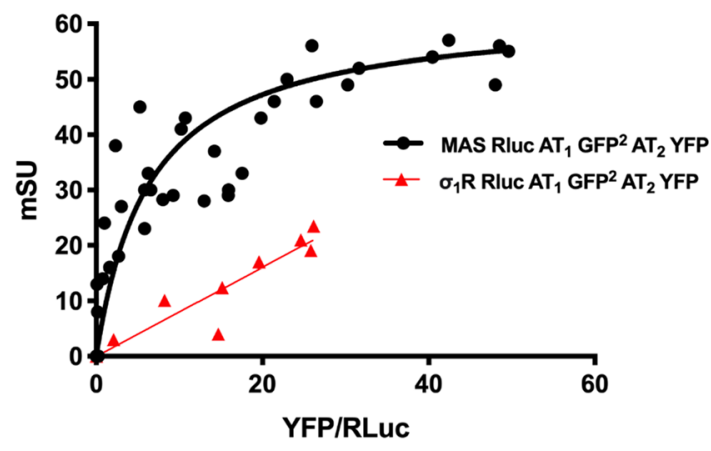

b BRET HEK-293T AT -Rluc AT $_{1}$-YFP

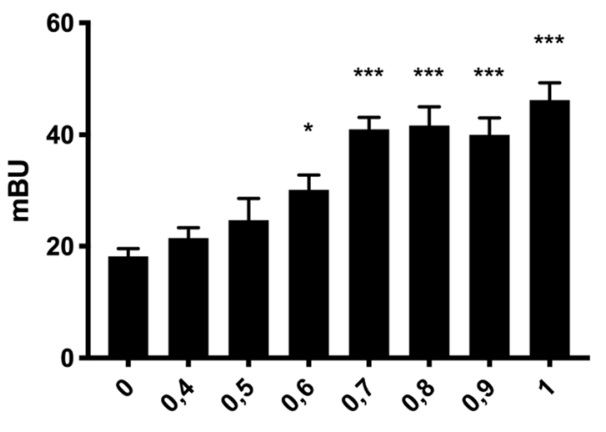

Mg MAS

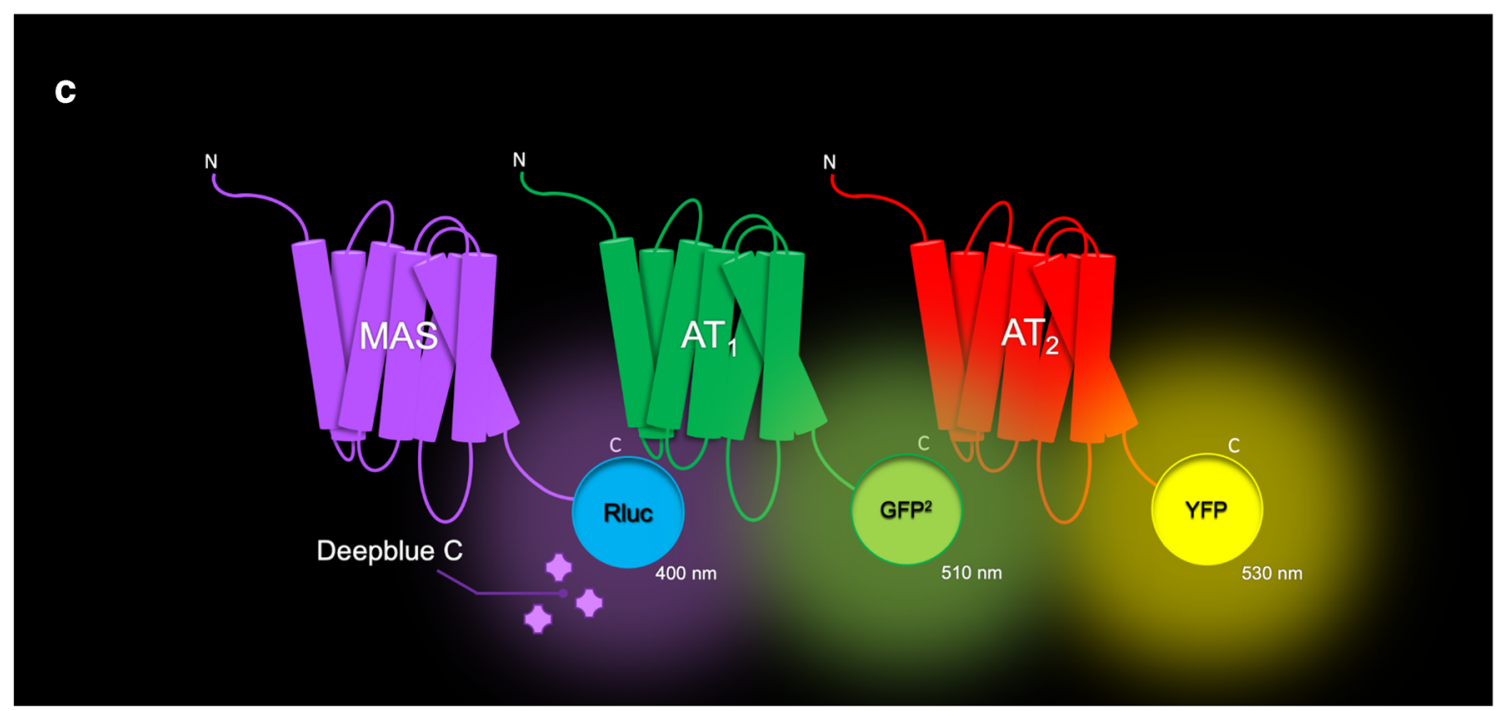

Fig. 2 All three RAS receptors interact in transfected HEK-293T cells. A Sequential resonance energy transfer $\left(\mathrm{SRET}^{2}\right)$ assays were performed in HEK-293T cells transfected with a constant amount of cDNA for MasRRluc $(0.6 \mu \mathrm{g})$ or $\sigma_{1} \mathrm{R}-\mathrm{R}$ luc $(0.3 \mu \mathrm{g})$ (as negative control), a constant amount of cDNA for $\mathrm{AT}_{1} \mathrm{R}-\mathrm{GFP}^{2}(1 \mu \mathrm{g})$, and increasing amounts of cDNA for $\mathrm{AT}_{2} \mathrm{R}$-YFP $(0.5$ to $4.1 \mu \mathrm{g})$. Values are the mean \pm SEM of 8 independent experiments performed in duplicate. B BRET assays were performed in HEK-293T cells transfected with a constant amount of

YFP fused to $\mathrm{AT}_{2} \mathrm{R}$ when forming receptor heterotrimers with MasR (Fig. 2B).

\section{Functional Characterization of $\mathrm{AT}_{1} \mathrm{R}-\mathrm{Mas} \mathrm{R}$ Heteromeric Complexes in HEK-293T Cells}

Upon identification of $\mathrm{AT}_{1}$-MasHets and $\mathrm{AT}_{2}$-MasHets in cotransfected HEK-293T cells, we characterized the functionality of these complexes. It is well established that the $\mathrm{AT}_{1}$ receptor couples to $\mathrm{G}_{\mathrm{q}}$ proteins, increasing inositol trisphosphate $\left(\mathrm{IP}_{3}\right)$ and diacylglycerol (DAG) levels by breaking phosphatidylinositol 4,5-bisphosphate $\left(\mathrm{PIP}_{2}\right)$ and subsequently releasing calcium (II) ion from endoplasmic reticulum channels, but it also couples to $G_{i}$ proteins, inhibiting adenylate cyclase and decreasing cAMP levels. In contrast, the MasR signal transduction pathway has not
cDNA for $\mathrm{AT}_{2} \mathrm{R}$-Rluc $(0.5 \mu \mathrm{g})$, a constant amount of cDNA for $\mathrm{AT}_{1} \mathrm{R}$ YFP $(3 \mu \mathrm{g})$, and increasing amounts of cDNA for MasR $(0$ to $1 \mu \mathrm{g})$. Values are the mean \pm SEM of 5 independent experiments performed in triplicate. One-way ANOVA followed by Bonferroni's multiple comparison post hoc tests were used for statistical analysis. C: Schematic representation of the $\mathrm{SRET}^{2}$ assay. $* p<0.05, * * * p<0.0001$ versus absence of MasR

yet been fully characterized. Calcium measurements were first addressed in HEK-293T cells transfected with cDNAs

Fig. 3 Functional analysis of $\mathrm{AT}_{1} \mathrm{R}-\mathrm{MasR}$ and $\mathrm{AT}_{2} \mathrm{R}-\mathrm{MasR}$ complexes in HEK-293T cells. HEK-293T cells were transfected with the cDNAs for MasR $(1 \mu \mathrm{g})$ and for either $\mathrm{AT}_{1} \mathrm{R}(1 \mu \mathrm{g})$ or $\mathrm{AT}_{2} \mathrm{R}(1 \mu \mathrm{g})$ and, in assays of $\mathrm{Ca}^{2+}$ determination, with the cDNA for an engineered calcium sensor, GCaMP6 $(1 \mu \mathrm{g})$. Transfected cells were pretreated with the selective antagonists $\left(300 \mathrm{nM}\right.$ candesartan for $\mathrm{AT}_{1} \mathrm{R}, 1 \mu \mathrm{M}$ PD123319 for $\mathrm{AT}_{2} \mathrm{R}$, and $500 \mathrm{nM} \mathrm{A779}$ for MasR) and subsequently treated with selective agonists (100 nM Ang II for $\mathrm{AT}_{1} \mathrm{R}, 300 \mathrm{nM}$ CGP-42112A for $\mathrm{AT}_{2} \mathrm{R}$, and $500 \mathrm{nM}$ Ang [1-7] for MasR). Thereafter, cytosolic calcium increases (A, B), intracellular cAMP levels $(\mathbf{C}, \mathbf{D})$, ERK1/2 phosphorylation $(\mathbf{E}, \mathbf{F})$, and the time-dependent DMR signal $(\mathbf{G}, \mathbf{H})$ were determined. Values are the mean \pm SEM of 6 independent experiments performed in triplicate. One-way ANOVA followed by Bonferroni's multiple comparison post hoc test were used for statistical analysis. $* \mathrm{p}<0.05$, $* * p<0.01, * * * p<0.001$ versus forskolin treatment in cAMP determinations or versus vehicle in pERK and DMR assays 
a

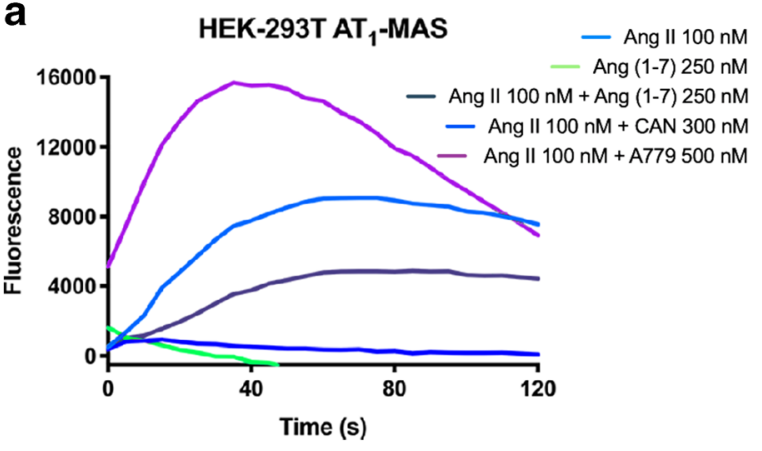

C

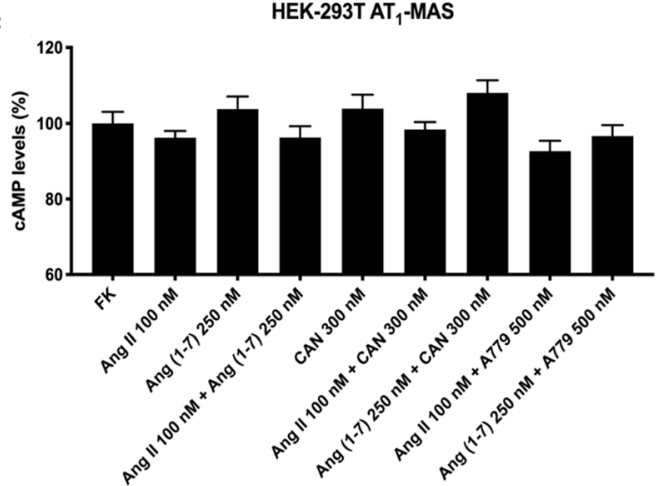

e

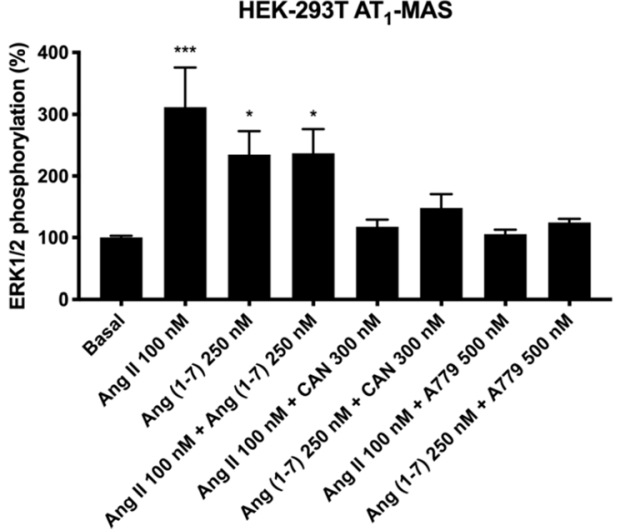

g

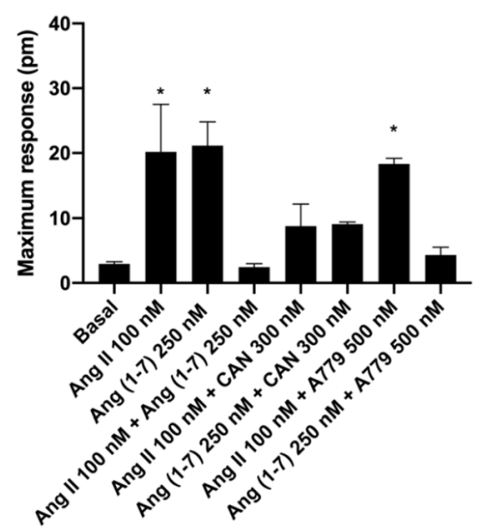

for $\mathrm{AT}_{1}$ and Mas receptors ( $1 \mu \mathrm{g}$ of cDNA each) and with the cDNA for the GCaMP6 calcium sensor (1 $\mu \mathrm{g}$ of cDNA). After treating cells with the $\mathrm{AT}_{1} \mathrm{R}$ agonist Ang II
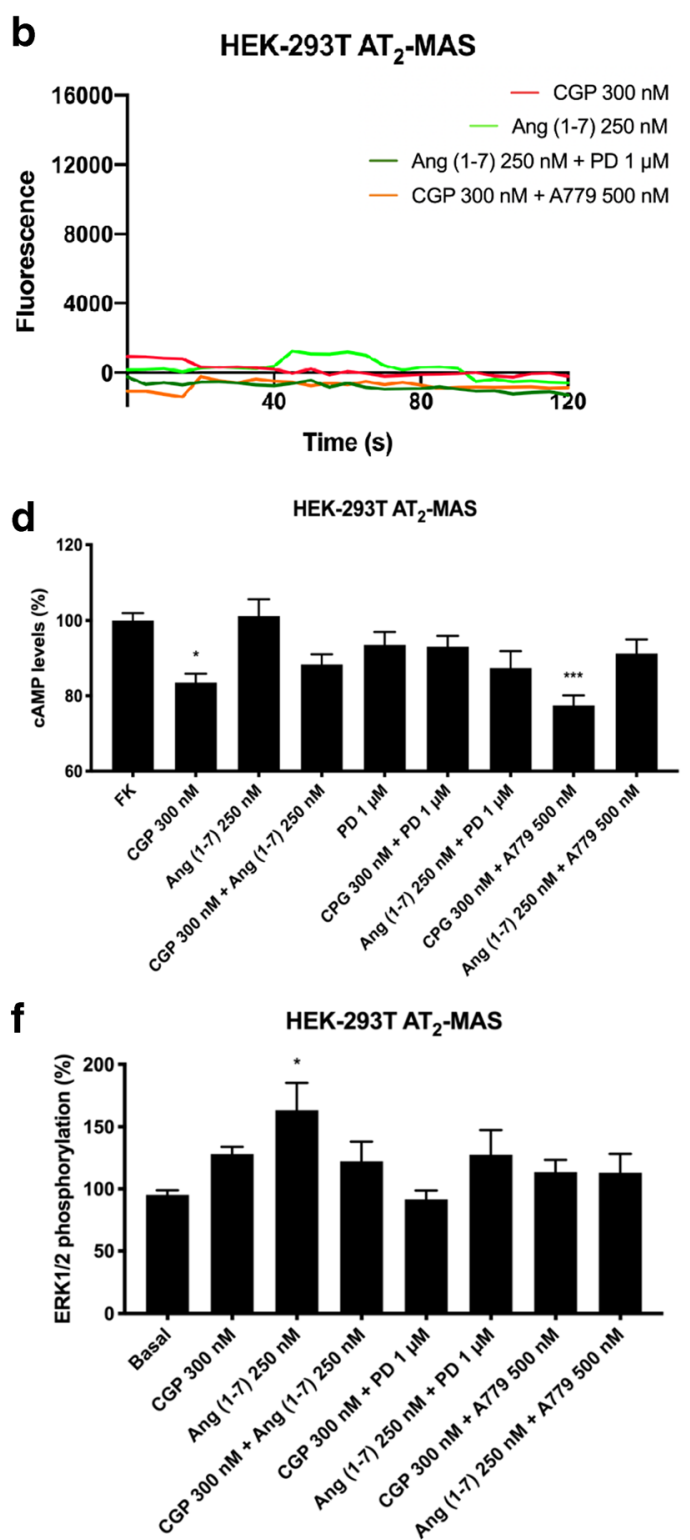

h

HEK-293T AT 2 - MAS

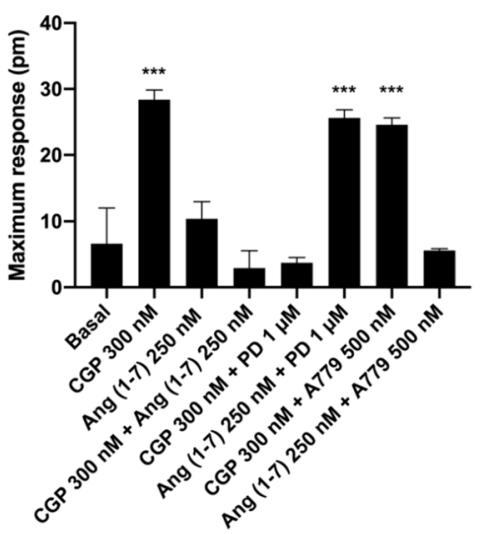

(100 nM), a characteristic curve of cytoplasmic transient $\left[\mathrm{Ca}^{2+}\right]$ increase was recorded. This ion mobilization was completely blocked in cells pretreated with the $\mathrm{AT}_{1} \mathrm{R}$ 
antagonist candesartan (300 nM; Fig. 3A). Interestingly, when cells were pretreated with the MasR antagonist A779 $(500 \mathrm{nM})$ followed by Ang II stimulation, we observed a marked increase in the calcium mobilization signal. Thus, MasR blockade potentiated $\mathrm{AT}_{1} \mathrm{R}$-mediated signaling in the $\mathrm{AT}_{1}$-MasHet context. The MasR agonist Ang(1-7) (250 nM) induced no effect, indicating that the MasR receptor does not couple with $\mathrm{G}_{\mathrm{q}}$.

Because of the controversy existing around the pathways engaged by MasR activation, we assayed whether the receptor agonist could affect the cytoplasmic levels of cAMP. As can be observed in Fig. 3C, activation of MasR in HEK-293T cells coexpressing $\mathrm{AT}_{1}$ and Mas receptors ( $1 \mu \mathrm{g}$ of cDNA each) did not have any effect on either basal or forskolin-induced cAMP levels, indicating that MasR does not couple with either $\mathrm{G}_{\mathrm{s}}$ or $\mathrm{G}_{\mathrm{i}}$. Similar results were obtained in cells only expressing MasR (Supplementary Figure S3). Furthermore, Ang II stimulation induced no effect in cells expressing $\mathrm{AT}_{1}$-MasHets (Fig. 3C).

We next addressed activation of the MAPK pathway, which is linked to the action of many GPCRs. When HEK293 $\mathrm{T}$ cells expressing $\mathrm{AT}_{1}$-MasHets were treated with Ang II or Ang(1-7), observed an increase in ERK1/2 phosphorylation. However, when cells were simultaneously stimulated with both agonists, the signal was reduced (Fig. 3E). This phenomenon - in which the signal in a combined treatment is lower than the sum of individual activation - is known as negative cross-talk and it can be used to detect $\mathrm{AT}_{1}$-MasHets in native tissues. Furthermore, when cells were pretreated with selective antagonists, we observed that A779 treatment blocked not only the MasR-induced signal but also the $\mathrm{AT}_{1} \mathrm{R}$-induced signal. Similarly, candesartan blocked both $\mathrm{AT}_{1} \mathrm{R}$-induced and MasR-induced signals (Fig. 3E). This phenomenon - by which the antagonist of one receptor in the heteromer blocks the signaling of the other protomer in the complex-is known as cross-antagonism and is a common print found for different GPCR heteromers.

Finally, when $\mathrm{AT}_{1}$-MasR complex signaling was assayed by using label-free DMR, a technique that detects cytoskeletal rearrangements upon receptor activation, negative cross-talk was detected when cells were costimulated; cross-antagonism was unidirectional because it was only detected with candesartan (Fig. 3G).

\section{Functional Characterization of $\mathrm{AT}_{2} \mathrm{R}-\mathrm{MasR}$ Heteromeric Complexes in HEK-293T Cells}

After confirming that MasR and $\mathrm{AT}_{1} \mathrm{R}$ arrange into a functional unit with novel properties, we proceeded to analyze the possibility of a similar scenario for $\mathrm{AT}_{2} \mathrm{R}$. The assays were similar to those described in the previous section. On the one hand, HEK-293T cells expressing $\mathrm{AT}_{2}$-MasHet and the GCaMP6 calcium sensor did not respond to the MasR agonist Ang [1-7] $(250 \mathrm{nM})$ or to the $\mathrm{AT}_{2} \mathrm{R}$ agonist CGP-42112A
(300 nM). These results fit with a lack of $\mathrm{G}_{\mathrm{q}}$ coupling (Fig. $3 \mathrm{~B})$. On the other hand, assays to determine cAMP levels showed that CGP-42112A decreased the forskolin-induced effect by approximately $20 \%$, whereas Ang [1-7] produced no effect (Fig. 3D). Similar results were obtained in cells expressing either $\mathrm{AT}_{2} \mathrm{R}$ (CGP-42112A) or MasR (Ang [1-7]) (Supplementary Figure S3). However, MasR activation partially blocked the $\mathrm{AT}_{2} \mathrm{R}$ signal. Interestingly, when HEK$293 \mathrm{~T}$ cells expressing $\mathrm{AT}_{2}$-MasHets were pretreated with the MasR antagonist $\mathrm{A} 779$ followed by $\mathrm{AT}_{2} \mathrm{R}$ activation, potentiation of $\mathrm{AT}_{2} \mathrm{R}$-mediated signaling was detected. Thus, these results show that MasR stimulation blocked $\mathrm{AT}_{2} \mathrm{R}$-induced signaling, whereas, remarkably, MasR blockade potentiated $\mathrm{AT}_{2} \mathrm{R}$ functionality. To further characterize signaling in $\mathrm{AT}_{1}$-MasHet-expressing cells, ERK1/2 phosphorylation and DMR were determined. Equivalent results were found in both assays, namely negative cross-talk when receptors were simultaneously activated (Fig. 3F, H) and partial crossantagonism in MAPK phosphorylation when cells were pretreated with selective antagonists. This partial crossantagonism was not detectable in DMR assays (Fig. 3H). MasR blockade did not potentiate $\mathrm{AT}_{2} \mathrm{R}$ functionality in MAPK activation or DMR assays.

\section{$A T_{1} R$-MasR and $A_{2}$ R-MasR Heteromeric Complexes in Neuronal Primary cultures}

Parkinson's disease is characterized by neuronal death and neuroinflammation, mainly affecting the indirect pathway of the basal ganglia, where angiotensin receptors are expressed. Thus, we isolated primary cultures of brain striatum to look for expression of angiotensin and Mas receptor complexes.

We first identified $\mathrm{AT}_{1}$-MasHets and $\mathrm{AT}_{2}$-MasHets in primary neurons by in situ PLA. Clusters of receptor pairs were identifiable as red fluorescent dots (Fig. 4A-D); 1.44 red dots/ cell were counted using primary antibodies against $\mathrm{AT}_{1} \mathrm{R}$ and MasR, and 0.63 red dots/cell were counted using primary antibodies against $\mathrm{AT}_{2} \mathrm{R}$ and MasR. The non-specific signal was equivalent to $0.17 \mathrm{red}$ dots/cell in the negative control.

Once expression of heteromers was demonstrated, we addressed their functionality in striatal neurons. Receptors in primary cultures of striatal neurons were treated with selective antagonists (candesartan for $\mathrm{AT}_{1} \mathrm{R}, \mathrm{PD} 123319$ for $\mathrm{AT}_{2} \mathrm{R}$, and A779 for MasR) and activated with agonists (Ang II for $\mathrm{AT}_{1} \mathrm{R}$, CGP-42112A for $\mathrm{AT}_{2} \mathrm{R}$, and Ang(1-7) for MasR), and cAMP levels and MAPK activation were analyzed.

In the cAMP assays, we observed that only $\mathrm{AT}_{2} \mathrm{R}$ activation produced a significant decrease in forskolin-induced cAMP levels (Fig. 4E-G). This effect was partially counteracted by MasR activation and thus congruent with the data obtained in the heterologous expression system. In addition, pretreatment with MasR antagonist potentiated $\mathrm{AT}_{2} \mathrm{R}$ signaling. 

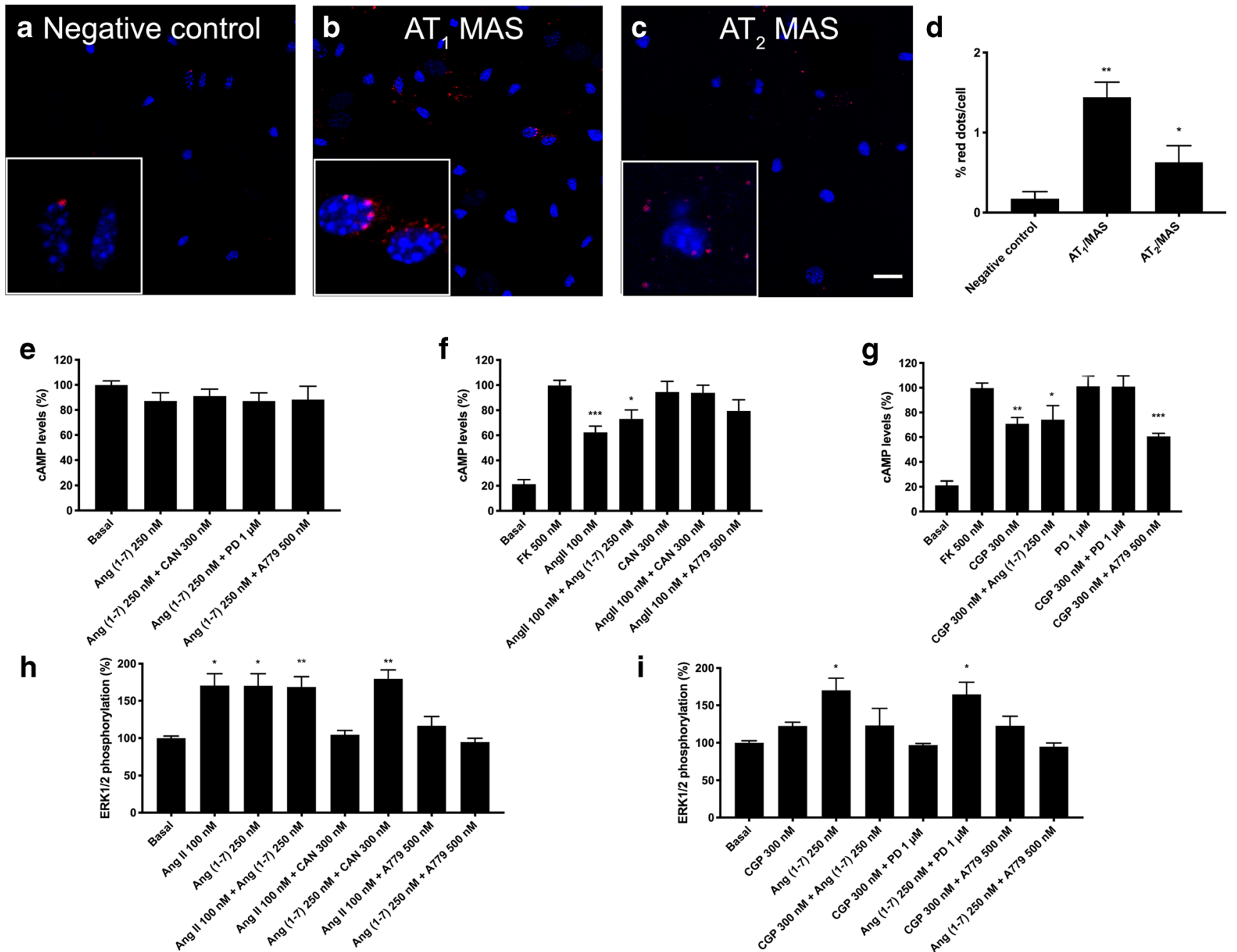

Fig. $4 \mathrm{AT}_{1}$-MasHet and $\mathrm{AT}_{2}$-MasHet expression and function in primary cultures of striatal neurons. A-C Expression of $\mathrm{AT}_{1}-\mathrm{MasHets}$ and $\mathrm{AT}_{2^{-}}$ MasHets heteromers was determined by proximity ligation assay (PLA), which was performed using specific primary antibodies against $\mathrm{AT}_{1}$, $\mathrm{AT}_{2}$, and Mas receptors. Confocal microscopy images (stacks of 4 consecutive planes) show heteroreceptor complexes; nuclei are Hoechst-stained (blue). Scale bar: $20 \mu \mathrm{m}$. D Bar graph showing the percentage of $\mathrm{AT}_{1} \mathrm{R}$-MasR and $\mathrm{AT}_{2} \mathrm{R}-\mathrm{MasR}$ clusters as red dots/cell compared with the negative control $\left({ }^{*} p<0.05,{ }^{*} p<0.01\right.$; Student's $t$ test $v s$ the negative control condition). For cAMP $(\mathbf{E}-\mathbf{G})$ or ERK1/2

Finally, except for $\mathrm{AT}_{2} \mathrm{R}$ in cells expressing $\mathrm{AT}_{2}$-MasHets, individual activation of receptors led to ERK1/2 phosphorylation. Furthermore, $\mathrm{AT}_{2} \mathrm{R}$ activation blunted the effect of MasR activation. Antagonists allowed us to identify unidirectional cross-antagonism, that is, the MasR antagonist blocked the $\mathrm{AT}_{1} \mathrm{R}$-induced but not the $\mathrm{AT}_{2} \mathrm{R}$-induced effect, whereas angiotensin receptor antagonists did not affect the link of MasR and the MAPK pathway (Fig. 4H, I). Compared with results in transfected HEK-293T cells, the cross-antagonism of $\mathrm{AT}_{1}$ and $\mathrm{AT}_{2}$ receptors over MasR was not observed in neurons.

\section{$\mathrm{AT}_{2} \mathrm{R}$-MasR Heteromeric Complex Expression in Microglia Treated or Not with LPS and IFN- $\gamma$}

In pathological conditions, microglia migrate to the injury site, releasing pro- and anti-inflammatory factors, and becoming key actors in regulating the neurodegenerative/ neuroprotective balance [64]. First, expression of the $\mathrm{AT}_{1} \mathrm{R}$-MasR and $\mathrm{AT}_{2} \mathrm{R}$-MasR heteromeric complexes was detected by PLA in primary microglia, both resting and activated. Microglia were activated by treating the cells for $48 \mathrm{~h}$ with $1 \mu \mathrm{M}$ LPS and $200 \mathrm{U} / \mathrm{mL}$ IFN- $\gamma$. As can be observed in Fig. 5, 3.8 and 4.4 red dots/cell were 

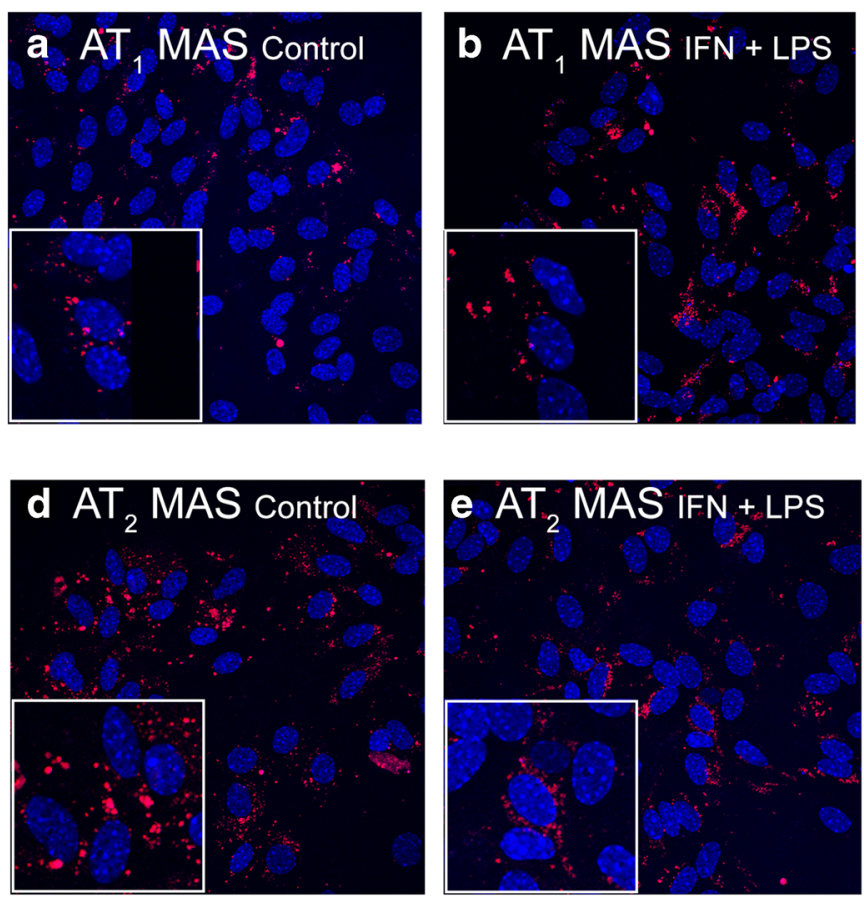

Fig. $5 \mathrm{AT}_{1}$-MasHet and $\mathrm{AT}_{2}$-MasHet expression in microglial primary cultures treated with LPS and IFN- $\gamma$. A-E Expression of $\mathrm{AT}_{1}$ R-MasR and $\mathrm{AT}_{2} \mathrm{R}$-MasR heteromers in primary microglial cultures was determined by proximity ligation assay (PLA), which was performed using specific primary antibodies against $\mathrm{AT}_{1}, \mathrm{AT}_{2}$, and Mas receptors. Confocal microscopy images (stacks of 4 consecutive planes) show

counted for $\mathrm{AT}_{1}$-MasHets (Fig. 5A) and $\mathrm{AT}_{2}$-MasHets (Fig. 5D), respectively, in resting microglia; in the negative control using the MasR primary antibody, only 0.2 red dots/cells were counted (Fig. 5C). These results indicate an expression level of $\mathrm{AT}_{1}$-MasHets and $\mathrm{AT}_{2}$-MasHets that seems markedly higher in resting microglia than in striatal neurons (see previous section). Interestingly, when the same experiment was performed in activated microglia, a significant decrease was observed in expression of the $\mathrm{AT}_{2} \mathrm{R}-\mathrm{MasR}$ complex (3.1 red dots/cell) (Fig. 5E) but not in expression of the $\mathrm{AT}_{1} \mathrm{R}-\mathrm{MasR}$ complex (4.2 red dots/cell) (Fig. 5B).

\section{AT ${ }_{1}$ R-MasR Complexes Show Negative Cross-talk in CAMP and MAPK Signaling Pathways in Microglia Treated or Not with LPS and IFN- $\gamma$}

Signaling outputs were used to look for any differential functionality of heteromers in resting versus activated microglial cells. As observed in Fig. 6A, B, neither $\mathrm{AT}_{1} \mathrm{R}$ nor MasR activation resulted in any cAMP level alteration in resting microglia. Also, activation of each receptor led to MAPK activation (Fig. 6C). Moreover, simultaneous coactivation of resting microglia with the two agonists induced negative cross-talk, whereas experiments with antagonists showed cross-antagonism. Interestingly, when primary cultures were
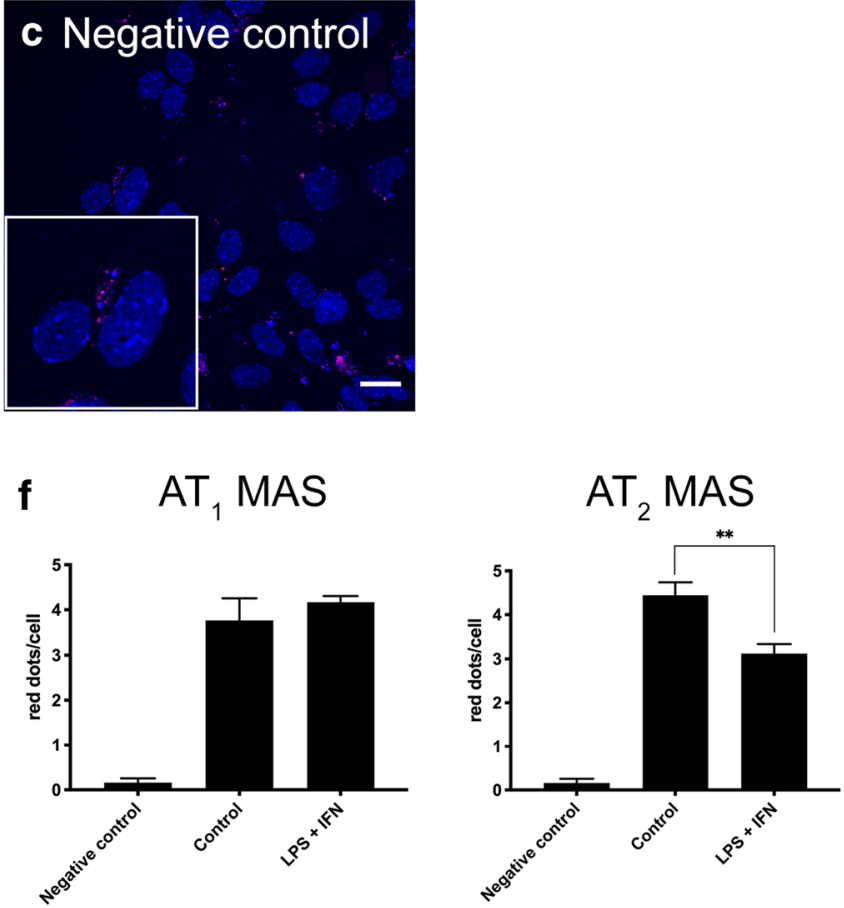

heteroreceptor complexes; nuclei are Hoechst-stained (blue). Microglial cultures were incubated for $48 \mathrm{~h}$ in the absence $(\mathbf{A}, \mathbf{C}, \mathbf{D})$ or in the presence $(\mathbf{B}, \mathbf{E})$ of $1 \mu \mathrm{M}$ LPS and $200 \mathrm{U} / \mathrm{mL}$ IFN- $\gamma$. Scale bar: $20 \mu \mathrm{m}$. $\mathbf{F}$ : Bar graph showing the percentage of $\mathrm{AT}_{1} \mathrm{R}-\mathrm{MasR}$ and $\mathrm{AT}_{2} \mathrm{R}-\mathrm{MasR}$ clusters as red dots/cell. ** $p<0.01$; Student's $t$ test versus resting cells

treated for $48 \mathrm{~h}$ with $1 \mathrm{mM}$ LPS and $200 \mathrm{U} / \mathrm{mL}$ IFN- $\gamma$, Ang II led to a significant $\mathrm{G}_{\mathrm{i}}$-mediated effect, indicating that the blockade of $\mathrm{AT}_{1} \mathrm{R}$ that occurred when forming complexes with MasR disappeared in activated microglia. This effect was potentiated when receptors were coactivated and crossantagonism was not detected (Fig. 6D). By analyzing ERK1/2 phosphorylation data, we observed a similar effect of the MasR agonist in both resting and activated microglia. However, as in resting microglia, negative cross-talk and cross-antagonism were observed (Fig. 6E). To summarize, in activated microglia, the $\mathrm{AT}_{1}$-MasHets seem to undergo structural reorganization favoring the action of Ang II on $\mathrm{G}_{\mathrm{i}^{-}}$ coupled $\mathrm{AT}_{1} \mathrm{R}$.

\section{$\mathrm{AT}_{2} \mathrm{R}$-MasR Complexes Show Negative Cross-talk in CAMP and MAPK Signaling Pathways in microglia Treated or Not with LPS and IFN- $\gamma$}

As in the previous section, we observed differential effects in resting and activated microglia when the $\mathrm{AT}_{2} \mathrm{R}$-MasR couple was analyzed with a functional perspective. The cAMP data indicated a non-significant effect upon $\mathrm{AT}_{2} \mathrm{R}$ or MasR activation in resting cells (Fig. 7A). Again, in resting microglia, a blockade of $\mathrm{G}_{\mathrm{i}}$-mediated $\mathrm{AT}_{2} \mathrm{R}$ function was detected when $\mathrm{AT}_{2} \mathrm{R}$ was coexpressed with MasR. In resting cells, only MasR was linked to MAPK pathway activation but with 
a

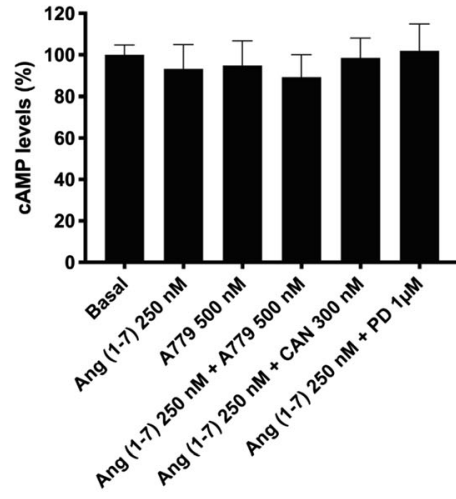

b

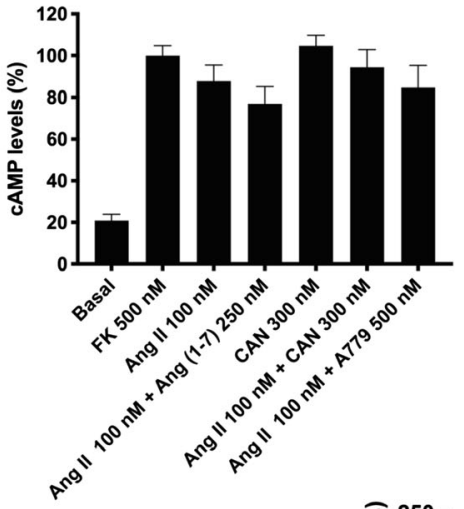

c

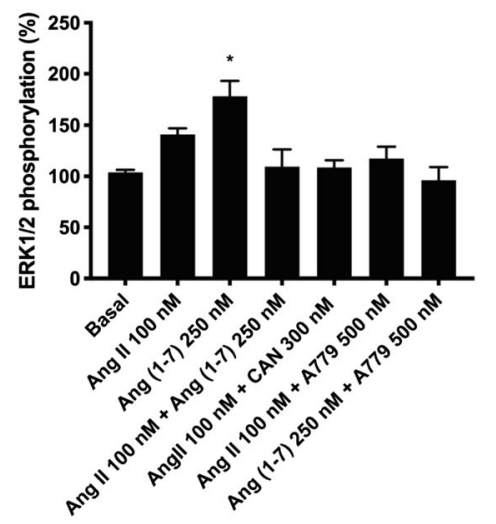

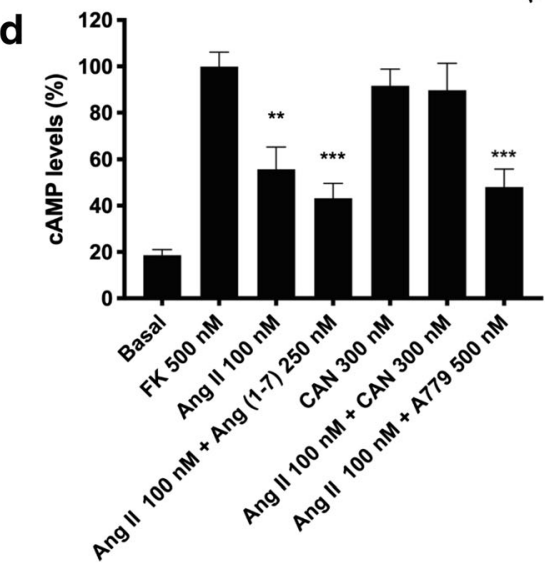

Fig. $6 \mathrm{AT}_{1}$-MasHet function in primary cultures of microglia. $\mathbf{A}-\mathbf{E}$ Microglia in primary cultures were incubated for $48 \mathrm{~h}$ with $1 \mu \mathrm{M}$ LPS and $200 \mathrm{U} / \mathrm{mL}$ IFN- $\gamma(\mathbf{D}, \mathbf{E})$ or vehicle $(\mathbf{A}-\mathbf{C})$. Then, cultures were pretreated with selective receptor antagonists $(300 \mathrm{nM}$ candesartan for $\mathrm{AT}_{1} \mathrm{R}, 1 \mu \mathrm{M}$ PD123319 for $\mathrm{AT}_{2} \mathrm{R}$, and $500 \mathrm{nM}$ A779 for MasR) and subsequently treated with selective agonists (100 nM Ang II for $\mathrm{AT}_{1} \mathrm{R}$, $300 \mathrm{nM}$ CGP-42112A for $\mathrm{AT}_{2} \mathrm{R}$, and $250 \mathrm{nM}$ Ang [1-7] for MasR).
Cytosolic cAMP levels $(\mathbf{A}, \mathbf{B}, \mathbf{D})$ and ERK1/2 phosphorylation $(\mathbf{C}, \mathbf{E})$ were subsequently determined. Values are the mean \pm SEM of 5 independent experiments performed in triplicate. One-way ANOVA followed by Bonferroni's multiple comparison post hoc test were used for statistical analysis. ${ }^{*} p<0.05,{ }^{*} p<0.01, * * * p<0.001$ versus basal treatment (A) or forskolin treatment (B, D) in cAMP measurements or versus vehicle in pERK measurements $(\mathbf{C}, \mathbf{E})$ marked negative cross-talk when the $\mathrm{AT}_{2} \mathrm{R}$ agonist was present and with a cross-antagonism effect (Fig. 7B). These results are similar to those obtained in the heterologous expression system.

In microglia activated for $48 \mathrm{~h}$ with $1 \mathrm{mM}$ LPS and $200 \mathrm{U} /$ $\mathrm{mL}$ IFN- $\gamma$, we observed that the $\mathrm{AT}_{2} \mathrm{R}$ agonist CGP-42112A induced a significant decrease in forskolin-induced cAMP levels (Fig. 7C). Activation of microglia provoked structural alterations in $\mathrm{AT}_{2}$-MasHets because cross-antagonism and negative cross-talk were not found; that is, there was no blockade by MasR over $\mathrm{AT}_{2} \mathrm{R}$. In terms of ERK1/2 phosphorylation, the results were similar to those found in resting cells: only MasR was linked to MAPK pathway activation, with marked negative cross-talk and cross-antagonism (Fig. 7D).

\section{Expression of Heteroreceptor Complexes in Parkinsonian and Dyskinetic Animals}

In situ PLA is instrumental in detecting receptor heteromer clusters in natural sources. We performed PLA in striatal sections from the 6-OH-dopamine-based PD model.
Assays were performed in sections from non-lesioned and lesioned hemispheres in three animal groups (see "Materials and Methods"): untreated, levodopa-treated non-dyskinetic, and levodopa-treated dyskinetic. Both $\mathrm{AT}_{1} \mathrm{R}-\mathrm{MasR}$ and $\mathrm{AT}_{2} \mathrm{R}$-MasR clusters were expressed but at relatively low levels (Fig. 8) and their expression was markedly enhanced in the lesioned hemisphere (Fig. 8). Levodopa treatment per se did not lead to significant modification of expression in parkinsonian animals; however, in dyskinetic animals (i.e., animals that developed dyskinesias upon treatment with the drug), expression was modified. Importantly, the expression in dyskinetic animals (with respect to non-dyskinetic animals) was lower in the case of the $\mathrm{AT}_{2} \mathrm{R}-\mathrm{Mas} \mathrm{R}$ heteromer but significantly higher in the case of $\mathrm{AT}_{1}$ R-MasR (Fig. 8).

\section{Discussion}

At the beginning of the twenty-first century, research on GPCRs uncovered a novel property resulting from the 
Fig. $7 \mathrm{AT}_{2}$-MasHet functionality in primary cultures of microglia. A-D Microglia in primary cultures were incubated for $48 \mathrm{~h}$ with $1 \mu \mathrm{M}$ LPS and $200 \mathrm{U} / \mathrm{mL}$ IFN- $\gamma(\mathbf{C}, \mathbf{D})$ or vehicle $(\mathbf{A}, \mathbf{B})$. Microglial cells were pretreated with selective receptor antagonists $(300 \mathrm{nM}$ candesartan for $\mathrm{AT}_{1} \mathrm{R}, 1 \mu \mathrm{M}$ PD123319 for $\mathrm{AT}_{2} \mathrm{R}$, and $500 \mathrm{nM} \mathrm{A779}$ for MasR) and subsequently treated with selective agonists (100 nM Ang II for $\mathrm{AT}_{1} \mathrm{R}, 300 \mathrm{nM}$ CGP42112A for $\mathrm{AT}_{2} \mathrm{R}$, and $250 \mathrm{nM}$ Ang [1-7] for MasR). Cytosolic cAMP levels $(\mathbf{A}, \mathbf{C})$ and ERK1/2 phosphorylation $(\mathbf{B}, \mathbf{D})$ were subsequently determined. Values are the mean \pm SEM of 5 independent experiments performed in triplicate. One-way ANOVA followed by Bonferroni's multiple comparison post hoc test were used for statistical analysis.

$* p<0.05, * * p<0.01$,

$* * * p<0.001$ versus forskolin treatment in cAMP measurements (A, C) or versus vehicle in pERK assays $(\mathbf{B}, \mathbf{D})$
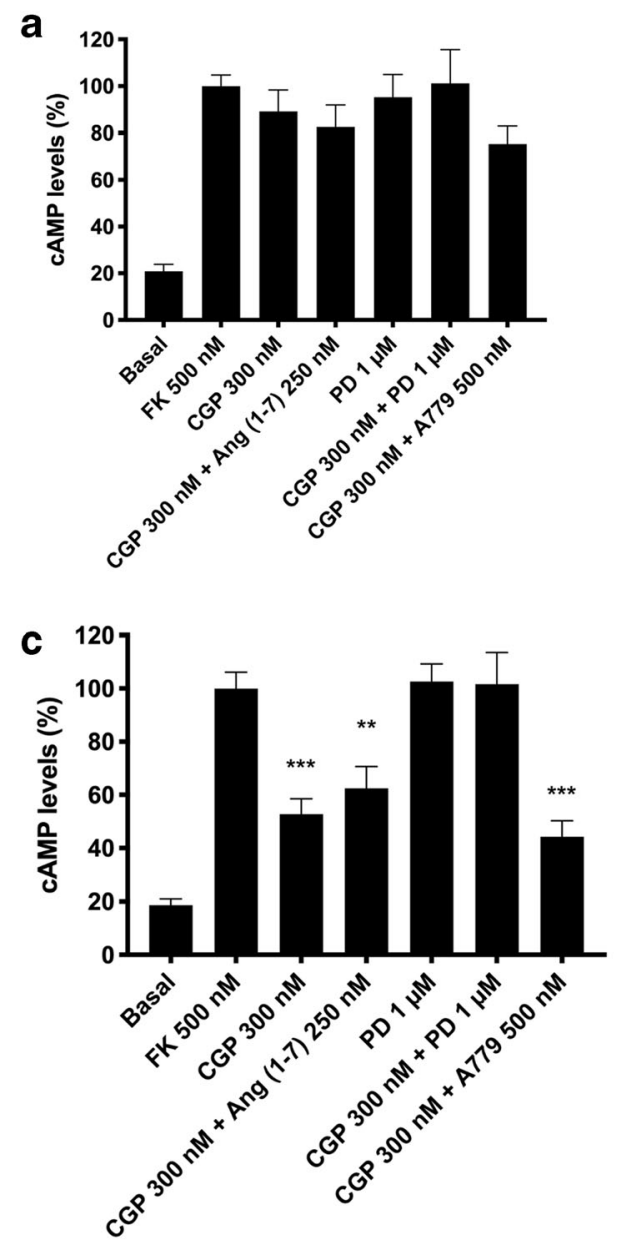

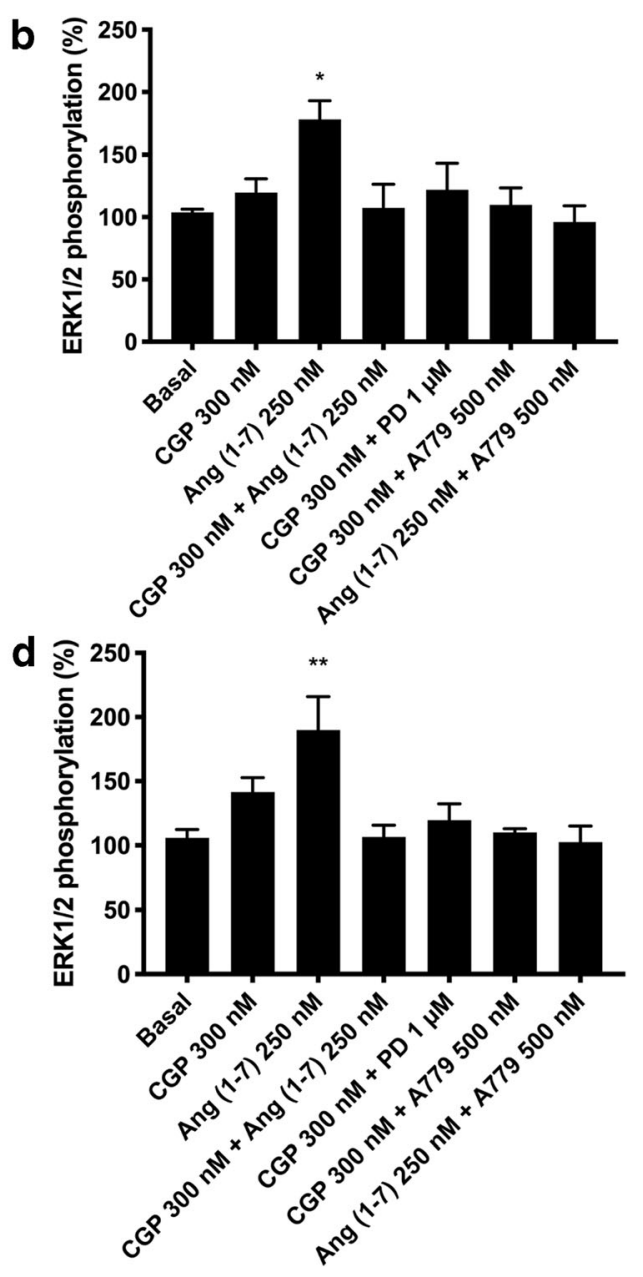

formation of heteroreceptor complexes. Receptor-receptor interactions lead to new functional units whose properties are different from those displayed by the individually acting receptors. Interestingly, consideration of receptor heteromers
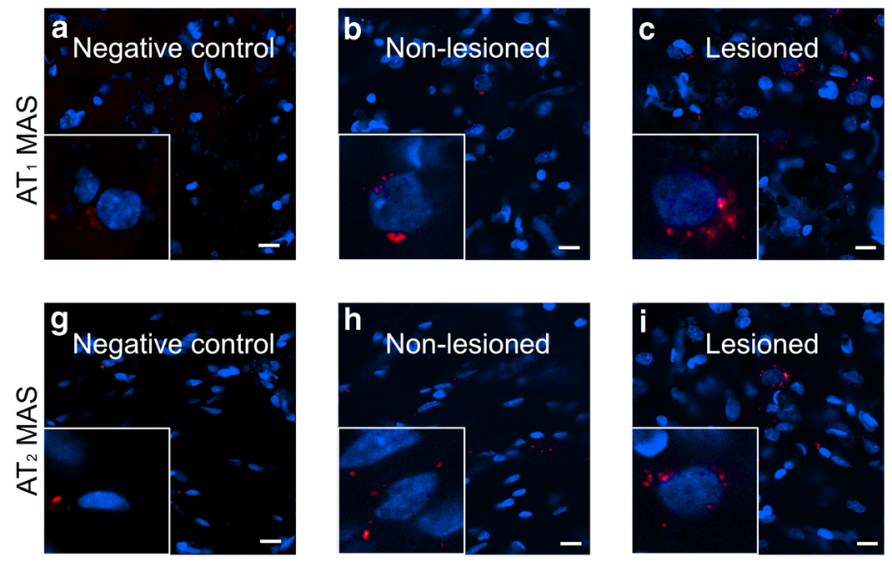

Fig. $8 \mathrm{AT}_{1}$-MasHet and $\mathrm{AT}_{2}$-MasHet complex expression in the striatum of lesioned and levodopa-treated animals. Heteroreceptor expression was assessed by the in situ proximity ligation assay (PLA) in the striatum of the different groups of animals treated as described in Methods. Graphs in was first suggested for neurodegenerative conditions such as those occurring in PD. Heteromers containing adenosine and cannabinoid receptors are among those relevant to striatal function [65-71]. The occurrence of angiotensin receptors in
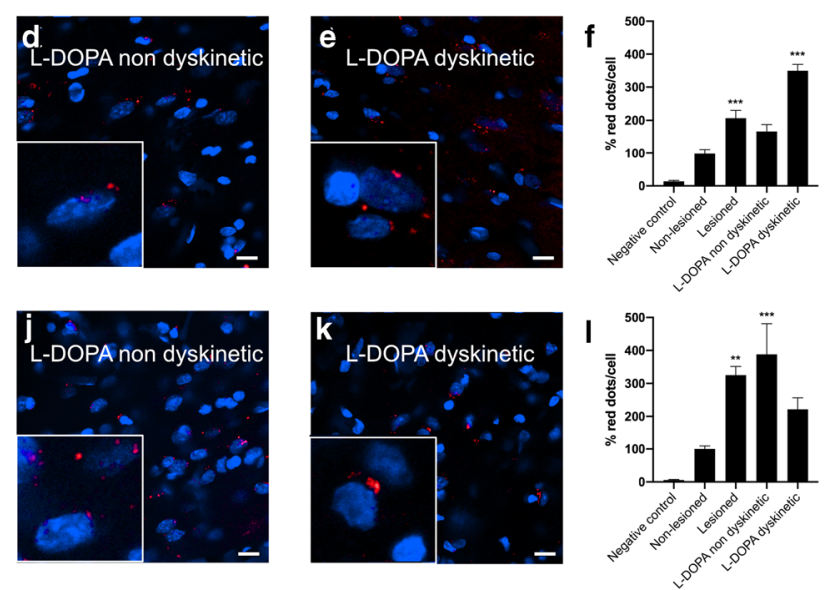

the right represent the quantification of the red labeling in the different groups calculated using Andy's algorithm. ${ }^{*} p<0.05$, ** $p<0.01$, $* * * p<0.001$ versus non-lesioned animals 
the nigra and the striatum was followed by the identification of complexes formed by $\mathrm{AT}_{1} \mathrm{R}$ and $\mathrm{AT}_{2} \mathrm{R}[39,42]$. In this paper, we showed that the Mas receptor forms heteroreceptor complexes with $\mathrm{AT}_{1} \mathrm{R}$ and $\mathrm{AT}_{2} \mathrm{R}$ and that such complexes are relevant for better understanding the role of RAS in neuroinflammation.

The RAS imbalance has been well studied in relation to blood pressure alterations, which are exacerbated by aging $[14,72,73]$. However, alterations in RAS balance upon aging affects almost any physiological process. RAS regulates functions in the kidneys, lungs, and brain and thus is key for maintaining homeostasis both in the periphery and in the CNS. Unbalanced RAS upon aging is seen as an opportunity to intervene using ligands of RAS receptors to combat neurological diseases whose main risk factor is age. Parkinson's and Alzheimer's diseases are the most prevalent aging-related diseases affecting the CNS [74-76]. It is tempting to speculate that RAS is center stage in understanding the greater severity of COVID-19 in older patients and the variety of symptoms ranging from asymptomatic to serious lung, kidney, immunological, and/or neurological manifestations [19, 21, 22, 77].

A review in 2009 questioned whether results associated with the RAS system were due to cross-talk or to heteromerization [78]. Both $\mathrm{AT}_{1} \mathrm{R}-\mathrm{AT}_{2} \mathrm{R}[39,79]$ and $\mathrm{AT}_{2} \mathrm{R}-\mathrm{MasR}$ interactions had previously been reported $[4,40]$. In 2018, it was suggested that MasR and $\mathrm{AT}_{2} \mathrm{R}$ were "joining forces" to counteract deleterious actions on blood pressure mediated by $\mathrm{AT}_{1} \mathrm{R}$ and that $\mathrm{AT}_{2}$-MasHets could help explain the functionality of $\mathrm{AT}_{1} \mathrm{R}$ [41]. A scenario of RAS receptors interacting with each other raised numerous questions, particularly to understand why receptors mediating opposing effects would "join forces." To approach the issue, two lines of inquiry are necessary: [1] assessing the expression levels of the different components of the system in targeted cells/tissues, heteromers included; and [2] deciphering the properties of the units resulting from receptorreceptor interactions. The functionality studies reported here show differential behaviors depending on the signaling pathway and inter-receptor interactions that lead to negative cross-talk, even reaching full blockade and cross-antagonism. Such counterbalancing effects occurred for both $\mathrm{AT}_{1}$-MasHets and $\mathrm{AT}_{2}$-MasHets. Cross-antagonism was reported for $\mathrm{AT}_{2^{-}}$ MasHet expressed in mouse astrocytes using the mRNA level of the CX3C chemokine receptor-1 as a read-out [40]. Apart from cross-antagonism, which is often a characteristic of heteromer expression, a novel feature that is also explained by inter-receptor interaction is that the antagonist of MasR increased the calcium peak elicited by the $\mathrm{AT}_{1} \mathrm{R}$ agonist $[31,80$, 81]. The properties of these heteromers must be considered to understand the efficacy of antihypertensive medication targeting RAS and for repurposing such approved drugs.

Unbalanced RAS associated with Parkinson's and Alzheimer's diseases opens new therapeutic perspectives. Pharmacological manipulation of RAS components has potential in PD [82]; it is suggested that antagonists already used to treat hypertension and able to cross the blood-brain barrier may be repurposed to treat PD [83]. On the one hand, the system has been extensively characterized in relation to nigral neurodegeneration [27, 72, 83-85]. On the other hand, there are confounding factors in assessing the risk of PD in individuals taking antihypertensive medication. This is due to the multiplicity of therapeutic choices but also to the fact that some drugs targeting RAS enter the brain (e.g., candesartan) [86], whereas others cannot cross the blood-brain barrier. Therefore, we cannot assess with certainty whether chronic administration of RAS-related antihypertensives is neuroprotective or whether they can delay neurodegeneration once the disease shows clinical symptoms. Selecting the most appropriate cell to be targeted is also important. It is feasible to target activated microglia to prevent neurodegeneration if the disease has a neuroinflammatory component. In addition, MasR is key for microglia-driven development of the retinal vasculature [87]. The results presented here and those related to expression of $\mathrm{AT}_{1} \mathrm{R}-\mathrm{AT}_{2} \mathrm{R}$ heteromers in striatal cells [42] suggest that MasR-related therapies to delay progression of PD should consider RAS components in microglia, with the ultimate goal of attenuating inflammation or skewing microglia toward the M2 neuroprotective phenotype [64]. RAS is well positioned to be targeted to polarization of microglia activated upon neuroinflammation [82]. In contrast to results in transfected HEK293T cells and activated microglia, we did not observe crossantagonism of $\mathrm{AT}_{1}$ and $\mathrm{AT}_{2}$ receptors over MasR in neurons. This, together with the lesser expression of MasR-containing heteromers, suggests that MasR functionality in neurons is not efficiently regulated by Ang II acting on $\mathrm{AT}_{1}$ or $\mathrm{AT}_{2}$ receptors.

Further parameters to consider are the expression of ACE1 and ACE2 and the possibility that these enzymes also interact with RAS receptors, thus affecting the local concentration of agonists of RAS receptors. In relation to COVID-19 management, it has been demonstrated that ACE2 interacts with $\mathrm{AT}_{1} \mathrm{R}$ [88]. Combining these results with the results presented here, we cannot rule out the occurrence of a functional unit constituted by an enzyme, two receptors, and the corresponding G-coupled proteins. The functionality of equivalent macromolecular complexes and the 3-dimensional structure underlying the particular functional features has been demonstrated for adenosine $A_{1}-A_{2 A}$ and $A_{2 A}-A_{2 B}$ receptors ( [33-38] and data in preparation). Both the allosteric modulation of ACE2 activity that results from the interaction with SARS-CoV viruses and the effect of viral infection on the surface expression of RAS components, heteromers included, need to be addressed.

Mechanistically, the two most relevant findings are the MasR-mediated regulation of cytosolic calcium mobilization triggered by $\mathrm{AT}_{1} \mathrm{R}$ agonists and the differential link between RAS and MAPK activation, depending on which heteromers are expressed in a given cell type and which 
agonist(s) is (are) affecting RAS receptors. Very few mechanisms lead to radical changes in the activation of the MAPK pathway. However, we present here data that show that one of the properties of RAS receptor heteromers is the possibility to engage or not this relevant pathway, depending on the overall RAS balance. Several years ago, we reported that histamine $\mathrm{H}_{3}$ receptor activation could not lead to ERK phosphorylation unless it formed a heteromer with the dopamine $\mathrm{D}_{1}$ receptor. $\mathrm{D}_{1^{-}}$ $\mathrm{H}_{3}$ receptor heteromers are unique devices directing histaminergic and dopaminergic signaling toward the MAPK pathway in a $\mathrm{G}_{\mathrm{i}}$-dependent but $\mathrm{G}_{\mathrm{s}}$-independent manner [89]. Remarkably, MasR in activated microglia is linked to MAPK pathway activation with marked negative cross-talk and cross-antagonism. In a complementary recent study, we showed that $\mathrm{AT}_{1}-\mathrm{AT}_{2}$ receptor heteromers are expressed in microglia where [1] they are upregulated in both parkinsonian conditions and in L-DOPAinduced dyskinesias, and [2] their activation is seemingly neuroprotective. The data shown in Fig. 8 suggest that expression of heteroreceptor complexes formed by MasR and either $\mathrm{AT}_{1} \mathrm{R}$ or $\mathrm{AT}_{2} \mathrm{R}$ is higher in the striatum of the lesioned hemisphere in the rat 6-OH-DA-based PD model. The marked increase in the case of $\mathrm{AT}_{1} \mathrm{R}-\mathrm{MasR}$ heteromers in dyskinetic animals open new therapeutic avenues for the assessment of this well-known side effect of antiparkinsonian medication. In microglia, a differential pharmacological trend, when Ang II receptor heteromers are compared with $\mathrm{AT}_{1}$-MasHets or $\mathrm{AT}_{2}$-MasHets, is cross-antagonism, which is not found in the former but in the latter. This is promising from a therapeutic point of view, because crossantagonism in $\mathrm{AT}_{1} \mathrm{R}_{-} \mathrm{AT}_{2} \mathrm{R}$ heteromers would lead to a dead end in terms of neuroprotection; instead, the antagonist of one Ang II receptor releases the brake on activation of the partner Ang II receptor within the $\mathrm{AT}_{1} \mathrm{R}-\mathrm{AT}_{2} \mathrm{R}$ heteromer [42].

Supplementary Information The online version contains supplementary material available at https://doi.org/10.1007/s13311-020-00986-4.

Required Author Forms Disclosure forms provided by the authors are available with the online version of this article.

Funding This work was partially supported by grants from the Spanish Ministry of Science and Innovation (MICINN) and/or Science, Innovation, and Universities; they may include EU FEDER funds (BFU2015-64405-R, SAF2016-77830-R, AARFD-17-503612, SAF2017-84117-R, RTI2018-094204-B-I00, and RTI2018-098830-BI00). The laboratory of the University of Barcelona is considered of excellence by the Regional Catalonian Government (grup consolidat \#2017 SGR 1497), which does not provide any specific funding for personnel, equipment, and reagents or for payment of services.

Data Availability The data that support the findings of this study are available from the corresponding author upon reasonable request.

\section{Compliance with Ethical Standards}

Conflict of Interest The authors declare that they have no conflict of interest.
Statement of Ethics Under the current legislation, obtaining protocol approval is not needed if animals are sacrificed to obtain a specific tissue. Animal handling, sacrifice and further experiments were conducted according to the guidelines set in Directive 2010/63/EU of the European Parliament and the Council of the European Union that is enforced in Spain by National and Regional organisms; also the 3R rule (replace, refine, reduce) for animal experimentation was taken into account.

\section{References}

1. Villela DC, Passos-Silva DG, Santos RAS. Alamandine: A new member of the angiotensin family. Vol. 23, Current Opinion in Nephrology and Hypertension. Curr Opin Nephrol Hypertens; 2014. p. $130-4$.

2. Souza LL, Duchene J, Todiras M, Azevedo LCP, Costa-Neto CM, Alenina N, et al. Receptor mas protects mice against hypothermia and mortality induced by endotoxemia. Shock. 2014;41(4):331-6.

3. Santos RAS, Simoes e Silva AC, Maric C, Silva DMR, Machado $\mathrm{RP}$, de Buhr I, et al. Angiotensin-(1-7) is an endogenous ligand for the G protein-coupled receptor Mas. Proc Natl Acad Sci U S A [Internet]. 2003;100(14):8258-63. Available from: http://www. pnas.org/content/100/14/8258.full

4. Villela D, Leonhardt J, Patel N, Joseph J, Kirsch S, Hallberg A, et al. Angiotensin type 2 receptor (AT 2 R) and receptor Mas: a complex liaison. Clin Sci [Internet]. 2015;128(4):227-34. Available from: http://www.clinsci.org/content/128/4/227. abstract\%5Cn, http://clinsci.org/lookup/10.1042/CS20130515

5. De Carvalho Santuchi M, Dutra MF, Vago JP, Lima KM, Galvão I, De Souza-Neto FP, et al. Angiotensin-(1-7) and Alamandine Promote Anti-inflammatory Response in Macrophages in Vitro and in Vivo. Mediators Inflamm [Internet]. 2019 [cited 2020 Apr 29];2019(1):2401081. Available from: https://doi.org/10. $1155 / 2019 / 2401081$

6. Clarke NE, Turner AJ. Angiotensin-Converting Enzyme 2: The First Decade. Int J Hypertens [Internet]. 2012;2012:1-12. Available from: http://www.hindawi.com/journals/ijhy/2012/ 307315/

7. Wan Y, Shang J, Graham R, Baric RS, Li F. Receptor Recognition by the Novel Coronavirus from Wuhan: an Analysis Based on Decade-Long Structural Studies of SARS Coronavirus. J Virol. 2020 Jan 29;94(7).

8. Shang J, Ye G, Shi K, Wan Y, Luo C, Aihara H, et al. Structural basis of receptor recognition by SARS-CoV-2. Nature. 2020 Mar 30;581(7807):221-4.

9. Kuhn JH, Li W, Choe H, Farzan M. Angiotensin-converting enzyme 2: A functional receptor for SARS coronavirus [Internet]. Vol. 61, Cellular and Molecular Life Sciences. 2004 [cited 2020 May 26]. p. 2738-43. Available from: https://www.nature.com/ articles/nature 02145

10. Li W, Moore MJ, Vasllieva N, Sui J, Wong SK, Berne MA, et al. Angiotensin-converting enzyme 2 is a functional receptor for the SARS coronavirus. Nature. 2003 Nov 27;426(6965):450-4.

11. Valenzuela R, Barroso-Chinea P, Villar-Cheda B, Joglar B, Muñoz A, Lanciego JL, et al. Location of Prorenin Receptors in Primate Substantia Nigra: Effects on Dopaminergic Cell Death. J Neuropathol Exp Neurol [Internet]. 2010 Nov [cited 2019 Sep 1];69(11):1130-42. Available from: http://www.ncbi.nlm.nih.gov/ pubmed/20940627

12. Jarrott B, Williams SJ. Chronic Brain Inflammation: The Neurochemical Basis for Drugs to Reduce Inflammation. Neurochem Res [Internet]. 2016 Mar 16 [cited 2019 Oct 4];41(3): 523-33. Available from: http://www.ncbi.nlm.nih.gov/pubmed/ 26177578 
13. Perez-Lloret S, Otero-Losada M, Toblli JE, Capani F. Reninangiotensin system as a potential target for new therapeutic approaches in Parkinson's disease. Expert Opin Investig Drugs [Internet]. 2017 Oct 3 [cited 2019 Oct 15];26(10):1163-73. Available from: https://www.tandfonline.com/full/10.1080/ 13543784.2017.1371133

14. Villar-Cheda B, Dominguez-Meijide A, Valenzuela R, Granado N, Moratalla R, Labandeira-Garcia JL. Aging-related dysregulation of dopamine and angiotensin receptor interaction. Neurobiol Aging [Internet]. 2014 Jul [cited 2019 Sep 1];35(7):1726-38. Available from: http://www.ncbi.nlm.nih.gov/pubmed/24529758

15. Rabie MA, Abd El Fattah MA, Nassar NN, Abdallah DM, ElAbhar HS. Correlation between angiotensin 1-7-mediated Mas receptor expression with motor improvement, activated STAT3/ SOCS3 cascade, and suppressed HMGB-1/RAGE/NF-kB signaling in 6-hydroxydopamine hemiparkinsonian rats. Biochem Pharmacol. 2020 Jan 1;171.

16. Mccarthy CA, Widdop RE, Deliyanti D, Wilkinson-Berka JL. Brain and retinal microglia in health and disease: An unrecognized target of the renin-angiotensin system. Vol. 40, Clinical and Experimental Pharmacology and Physiology. 2013. p. 571-9.

17. Gironacci MM, Vicario A, Cerezo G, Silva MG. The depressor axis of the renin-angiotensin system and brain disorders: A translational approach. Vol. 132, Clinical Science. Portland Press Ltd; 2018. p. 1021-38.

18. Garrido-Gil P, Rodriguez-Perez AI, Fernandez-Rodriguez P, Lanciego JL, Labandeira-Garcia JL. Expression of angiotensinogen and receptors for angiotensin and prorenin in the rat and monkey striatal neurons and glial cells. Brain Struct Funct [Internet]. 2017 Aug 4 [cited 2019 Oct 8];222(6):2559-71. Available from: http:// www.ncbi.nlm.nih.gov/pubmed/28161727

19. Haddadi K, Ghasemian R, Shafizad M. Basal Ganglia Involvement and Altered Mental Status: A Unique Neurological Manifestation of Coronavirus Disease 2019. Cureus. 2020 Apr 28;12(4).

20. Lahiri D, Ardila A. COVID-19 Pandemic: A Neurological Perspective. Cureus. 2020 Apr 29;12(4).

21. Baig AM, Sanders EC. Potential Neuroinvasive Pathways of SARS-CoV-2: Deciphering the Spectrum of Neurological Deficit Seen in Coronavirus Disease 2019 (COVID-19). J Med Virol [Internet]. 2020 Jun 3 [cited 2020 Jun 6]; Available from: http:// www.ncbi.nlm.nih.gov/pubmed/32492193

22. Brun G, Hak JF, Coze S, Kaphan E, Carvelli J, Girard N, et al. COVID-19-White matter and globus pallidum lesions: Demyelination or small-vessel vasculitis? Neurol Neuroimmunol neuroinflammation. $2020 \mathrm{Jul}$ 1;7(4).

23. Dixon L, Varley J, Gontsarova A, Mallon D, Tona F, Muir D, et al. COVID-19-related acute necrotizing encephalopathy with brain stem involvement in a patient with aplastic anemia. Neurol Neuroimmunol neuroinflammation [Internet]. 2020 Sep 3 [cited 2020 Jun 6];7(5). Available from: http://www.ncbi.nlm.nih.gov/ pubmed/32457227

24. Rodriguez-Perez AI, Garrido-Gil P, Pedrosa MA, Garcia-Garrote M, Valenzuela R, Navarro G, et al. Angiotensin type 2 receptors: Role in aging and neuroinflammation in the substantia nigra. Brain Behav Immun [Internet]. 2019 [cited 2020 Jun 6]; Available from: https://pubmed.ncbi.nlm.nih.gov/31863823/

25. Dominguez-Meijide A, Rodriguez-Perez AI, Diaz-Ruiz C, Guerra MJ, Labandeira-Garcia JL. Dopamine modulates astroglial and microglial activity via glial renin-angiotensin system in cultures. Brain Behav Immun [Internet]. 2017 May [cited 2019 Oct 4];62: 277-90. Available from: http://www.ncbi.nlm.nih.gov/pubmed/ 28232171

26. Labandeira-Garcia JL, Rodriguez-Pallares J, Dominguez-Meijide A, Valenzuela R, Villar-Cheda B, Rodríguez-Perez AI. Dopamine-angiotensin interactions in the basal ganglia and their relevance for Parkinson's disease. Mov Disord [Internet]. 2013
Sep [cited 2019 Sep 1];28(10):1337-42. Available from: http:// doi.wiley.com/10.1002/mds. 25614

27. Costa-Besada MA, Valenzuela R, Garrido-Gil P, Villar-Cheda B, Parga JA, Lanciego JL, et al. Paracrine and Intracrine Angiotensin 1-7/Mas Receptor Axis in the Substantia Nigra of Rodents, Monkeys, and Humans. Mol Neurobiol [Internet]. 2018 Jul 30 [cited 2019 Aug 30];55(7):5847-67. Available from: http://www.ncbi. nlm.nih.gov/pubmed/29086247

28. Jiang M, Huang W, Wang Z, Ren F, Luo L, Zhou J, et al. Antiinflammatory effects of Ang-(1-7) via TLR4-mediated inhibition of the JNK/FoxO1 pathway in lipopolysaccharide-stimulated RAW264.7 cells. Dev Comp Immunol. 2019 Mar 1;92:291-8.

29. Ferré S, Baler R, Bouvier M, Caron MG, Devi LA, Durroux T, et al. Building a new conceptual framework for receptor heteromers. Nat Chem Biol [Internet]. 2009 Mar [cited 2020 May 11];5(3):131-4. Available from: http://www.ncbi.nlm.nih.gov/pubmed/19219011

30. Franco R, Martínez-Pinilla E, Lanciego JLJLJL, Navarro G. Basic Pharmacological and Structural Evidence for Class A G-ProteinCoupled Receptor Heteromerization. Front Pharmacol [Internet]. 2016 Jan 31 [cited 2016 Apr 12];7(MAR):76. Available from: http://www.ncbi.nlm.nih.gov/pubmed/27065866

31. Franco N, Franco R. Understanding the added value of g-proteincoupled receptor heteromers. Scientifica (Cairo) [Internet]. 2014;2014:362937. Available from: http://www.pubmedcentral. nih.gov/articlerender.fcgi ?artid=4017843\&tool= pmcentrez\&rendertype $=$ abstract

32. Gupta A, Mulder J, Gomes I, Rozenfeld R, Bushlin I, Ong E, et al. Increased abundance of opioid receptor heteromers after chronic morphine administration. Sci Signal [Internet]. 2010 Jan [cited 2016 Feb 23];3(131):ra54. Available from: http://www. pubmedcentral.nih.gov/articlerender.fcgi?artid=3125674\&tool $=$ pmcentrez\&rendertype $=$ abstract

33. Ciruela F, Casadó V, Rodrigues R, Luján R, Burgueño J, Canals M, et al. Presynaptic Control of Striatal Glutamatergic Neurotransmission by Adenosine A1-A2A Receptor Heteromers. J Neurosci [Internet]. 2006 Feb 15 [cited 2015 Mar 21];26(7):2080-7. Available from: http://www.jneurosci.org/cgi/10.1523/JNEUROSCI.3574-05.2006

34. Ciruela F, Ferré S, Casadó V, Cortés A, Cunha R, Lluis C, et al. Heterodimeric adenosine receptors: A device to regulate neurotransmitter release. Cell Mol Life Sci. 2006;63(21):2427-31.

35. Cristóvão-Ferreira S, Navarro G, Brugarolas M, Pérez-Capote K, Vaz $\mathrm{SH}$, Fattorini $\mathrm{G}$, et al. A1R-A2AR heteromers coupled to Gs and $\mathrm{G}$ i/o proteins modulate GABA transport into astrocytes. Purinergic Signal [Internet]. 2013 Sep [cited 2015 Dec 14];9(3):433-49. Available from: http://www.pubmedcentral.nih.gov/articlerender.fcgi? artid= 3757138\&tool=pmcentrez\&rendertype $=$ abstract

36. Navarro G, Cordomí A, Brugarolas M, Moreno E, Aguinaga D, Pérez-Benito L, et al. Cross-communication between Gi and Gs in a G-protein-coupled receptor heterotetramer guided by a receptor C-terminal domain. BMC Biol [Internet]. 2018;16:24(1):1-15. Available from: https://bmcbiol.biomedcentral.com/articles/10. 1186/s12915-018-0491-x

37. Navarro G, Cordomí A, Zelman-Femiak M, Brugarolas M, Moreno E, Aguinaga D, et al. Quaternary structure of a G-protein-coupled receptor heterotetramer in complex with $\mathrm{Gi}$ and Gs. BMC Biol [Internet]. 2016 Jan 5 [cited 2016 Apr 8];14(1):26. Available from: http:// bmcbiol.biomedcentral.com/articles/10.1186/s12915-016-0247-4

38. Hinz S, Navarro G, Borroto-Escuela D, Seibt BF, Ammon C, Filippo E De, et al. Adenosine A2A receptor ligand recognition and signaling is blocked by A2B receptors. Oncotarget [Internet]. 2018 Mar 2 [cited 2018 Apr 5];9(17):13593-611. Available from: http://www.ncbi.nlm.nih.gov/pubmed/29568380

39. Porrello ER, Pfleger KDG, Seeber RM, Qian H, Oro C, Abogadie $\mathrm{F}$, et al. Heteromerization of angiotensin receptors changes trafficking and arrestin recruitment profiles. Cell Signal [Internet]. 2011 
Nov [cited 2019 Aug 30];23(11):1767-76. Available from: http:// www.ncbi.nlm.nih.gov/pubmed/21740964

40. Leonhardt J, Villela DC, Teichmann A, Münter L-M, Mayer MC, Mardahl M, et al. Evidence for Heterodimerization and Functional Interaction of the Angiotensin Type 2 Receptor and the Receptor MASNovelty and Significance. Hypertension [Internet]. 2017 Jun [cited 2019 Aug 30];69(6):1128-35. Available from: http://hyper. ahajournals.org/lookup/10.1161/HYPERTENSIONAHA.116.08814

41. Patel S, Hussain T. Dimerization of AT2 and Mas Receptors in Control of Blood Pressure. Curr Hypertens Rep [Internet]. 2018 May 1 [cited 2018 May 6];20(5):1-9. Available from: http:// www.ncbi.nlm.nih.gov/pubmed/29717388

42. Rivas-Santisteban R, Rodriguez-Perez AI, Muñoz A, Reyes-Resina I, Labandeira-García JL, Navarro G, et al. Angiotensin AT1and AT2receptor heteromer expression in the hemilesioned rat model of Parkinson's disease that increases with levodopa-induced dyskinesia. J Neuroinflammation. 2020 May 29;17(1).

43. Newell EA, Exo JL, Verrier JD, Jackson TC, Gillespie DG, Janesko-Feldman K, et al. 2',3'-cAMP, 3'-AMP, 2'-AMP and adenosine inhibit TNF- $\alpha$ and CXCL10 production from activated primary murine microglia via A2A receptors. Brain Res. 2015 Jan;1594:27-35.

44. Hradsky J, Mikhaylova M, Karpova A, Kreutz MR, Zuschratter W. Super-resolution microscopy of the neuronal calcium-binding proteins Calneuron-1 and Caldendrin. Methods Mol Biol [Internet]. 2013 [cited 2017 Jun 4];963:147-69. Available from: http://link. springer.com/10.1007/978-1-62703-230-8_10

45. Reyes-Resina I, Navarro G, Aguinaga D, Canela EI, Schoeder CT, Załuski M, et al. Molecular and functional interaction between GPR18 and cannabinoid CB2G-protein-coupled receptors. Relevance in neurodegenerative diseases. Biochemical Pharmacology [Internet]. 2018 Jun [cited 2018 Jun 26];In the Press. Available from: http://linkinghub.elsevier.com/retrieve/pii/ S0006295218302090

46. Navarro G, Borroto-Escuela D, Angelats E, Etayo I, Reyes-Resina I, Pulido-Salgado M, et al. Receptor-heteromer mediated regulation of endocannabinoid signaling in activated microglia. Role of CB1 and $\mathrm{CB} 2$ receptors and relevance for Alzheimer's disease and levodopa-induced dyskinesia. Brain Behav Immun [Internet]. 2018 Aug [cited 2018 Feb 3];67:139-51. Available from: http:// linkinghub.elsevier.com/retrieve/pii/S0889159117304038

47. Farré D, Muñoz A, Moreno E, Reyes-Resina I, Canet-Pons J, Dopeso-Reyes IG, et al. Stronger Dopamine D1 ReceptorMediated Neurotransmission in Dyskinesia. Mol Neurobiol [Internet]. 2015 Oct 26 [cited 2014 Oct 29];52(3):1408-20. Available from: http://www.ncbi.nlm.nih.gov/pubmed/25344317

48. Pinna A, Bonaventura J, Farré D, Sánchez M, Simola N, Mallol J, et al. 1-DOPA disrupts adenosine A2A-cannabinoid CB1-dopamine D2 receptor heteromer cross-talk in the striatum of hemiparkinsonian rats: Biochemical and behavioral studies. Exp Neurol [Internet]. 2014 Mar [cited 2015 Mar 17];253:180-91. Available from: http://www.ncbi.nlm.nih.gov/pubmed/24412491

49. Muñoz A, Garrido-Gil P, Dominguez-Meijide A, Labandeira-Garcia JL. Angiotensin type 1 receptor blockage reduces 1-dopa-induced dyskinesia in the 6-OHDA model of Parkinson's disease. Involvement of vascular endothelial growth factor and interleukin-1ß. Exp Neurol [Internet]. 2014 Nov [cited 2017 Aug 2];261:720-32. Available from: https://doi.org/10.1016/j.expneurol.2014.08.019

50. Winkler C, Kirik D, Björklund A, Cenci MA. L-DOPA-induced dyskinesia in the intrastriatal 6-hydroxydopamine model of parkinson's disease: relation to motor and cellular parameters of nigrostriatal function. Neurobiol Dis. 2002;10(2):165-86.

51. Schallert T, Kozlowski DA, Humm JL CR. Use-dependent structural events in recovery of function. Adv Neurol. 1997;73(1):229-38.

52. Kirik D, Winkler C, Björklund A. Growth and functional efficacy of intrastriatal nigral transplants depend on the extent of nigrostriatal degeneration. J Neurosci [Internet]. 2001 Apr 15 [cited 2016 Dec 7];21(8):2889-96. Available from: http://www.ncbi.nlm. nih.gov/pubmed/11306640

53. Lee CS, Cenci MA, Schulzer M, Björklund A. Embryonic ventral mesencephalic grafts improve levodopa-induced dyskinesia in a rat model of Parkinson's disease. Brain [Internet]. 2000 Jul [cited 2016 Dec 7];123 ( Pt 7:1365-79. Available from: http://www.ncbi.nlm. nih.gov/pubmed/10869049

54. Lundblad M, Andersson M, Winkler C, Kirik D, Wierup N, Cenci Nilsson MA. Pharmacological validation of behavioural measures of akinesia and dyskinesia in a rat model of Parkinson's disease. Eur J Neurosci [Internet]. 2002 Jan [cited 2016 Dec 7];15(1):120-32. Available from: http://www.ncbi.nlm.nih.gov/pubmed/11860512

55. Benito C, Núñez E, Tolón RM, Carrier EJ, Rábano A, Hillard CJ, et al. Cannabinoid CB2 receptors and fatty acid amide hydrolase are selectively overexpressed in neuritic plaque-associated glia in Alzheimer's disease brains. J Neurosci [Internet]. 2003 Dec 3 [cited 2016 Feb 18];23(35):11136-41. Available from: http://www.ncbi. nlm.nih.gov/pubmed/14657172

56. De Filippis D, Steardo A, D’Amico A, Scuderi C, Cipriano M, Esposito G, et al. Differential Cannabinoid Receptor Expression during Reactive Gliosis: a Possible Implication for a Nonpsychotropic Neuroprotection. Sci World J [Internet]. 2009 Mar 31 [cited 2016 Dec 7];9:229-35. Available from: http:// www.ncbi.nlm.nih.gov/pubmed/19347234

57. Ohlin KE, Sebastianutto I, Adkins CE, Lundblad C, Lockman PR, Cenci MA. Impact of L-DOPA treatment on regional cerebral blood flow and metabolism in the basal ganglia in a rat model of Parkinson's disease. Neuroimage [Internet]. 2012 May 15 [cited 2016 Dec 7];61(1):228-39. Available from: http://linkinghub. elsevier.com/retrieve/pii/S1053811912002510

58. Navarro G, Hradsky J, Lluís C, Casadó V, McCormick PJ, Kreutz $\mathrm{MR}$, et al. NCS-1 associates with adenosine $\mathrm{A}(2 \mathrm{~A})$ receptors and modulates receptor function. Front Mol Neurosci [Internet]. 2012 Apr;5(April):53. Available from: http://www.pubmedcentral.nih. gov/articlerender.fcgi ?artid=3328853\&tool= pmcentrez\&rendertype $=$ abstract

59. Chen T-W, Wardill TJ, Sun Y, Pulver SR, Renninger SL, Baohan A, et al. Ultrasensitive fluorescent proteins for imaging neuronal activity. Nature [Internet]. 2013 Jul 17 [cited 2017 Jun 4];499(7458):295-300. Available from: http://www.ncbi.nlm. nih.gov/pubmed/23868258

60. Law AMK, Yin JXM, Castillo L, Young AIJ, Piggin C, Rogers S, et al. Andy's Algorithms: new automated digital image analysis pipelines for FIJI. Sci Rep [Internet]. 2017 Dec 16 [cited 2019 Aug 26];7(1):15717. Available from: http://www.nature.com/ articles/s41598-017-15885-6

61. Giles ME, Fernley RT, Nakamura Y, Moeller I, Aldred GP, Ferraro $\mathrm{T}$, et al. Characterization of a specific antibody to the rat angiotensin II AT1 receptor. J Histochem Cytochem [Internet]. 1999 [cited 2020 Oct 25];47(4):507-15. Available from: https://pubmed.ncbi. nlm.nih.gov/10082752/

62. Valenzuela R, Costa-Besada MAMA, Iglesias-Gonzalez J, PerezCostas E, Villar-Cheda B, Garrido-Gil P, et al. Mitochondrial angiotensin receptors in dopaminergic neurons. Role in cell protection and aging-related vulnerability to neurodegeneration. Cell Death Dis [Internet]. 2016 Oct 20 [cited 2019 Sep 1];7(10):e2427. Available from: https://doi.org/10.1038/cddis.2016.327\% 5Cnhttp://www.ncbi.nlm.nih.gov/pubmed/27763643

63. Carriba P, Navarro G, Ciruela F, Ferré S, Casadó V, Agnati L, et al. Detection of heteromerization of more than two proteins by sequential BRET-FRET. Nat Methods [Internet]. 2008 Aug [cited 2015 Nov 22];5(8):727-33. Available from: http://www.ncbi.nlm.nih. gov/pubmed/18587404

64. Franco R, Fernández-Suárez D. Alternatively activated microglia and macrophages in the central nervous system. Prog Neurobiol 
[Internet]. 2015 Jun 8 [cited 2015 Jun 14];131:65-86. Available from: http://www.ncbi.nlm.nih.gov/pubmed/26067058

65. Ferré S, Goldberg SR, Lluis C, Franco R. Looking for the role of cannabinoid receptor heteromers in striatal function. Neuropharmacology [Internet]. 2009 Jan [cited 2017 Dec 27];56(SUPPL. 1):226-34. Available from: http://www.ncbi. nlm.nih.gov/pubmed/18691604

66. Martínez-Pinilla E, Rico AJ, Rivas-Santisteban R, Lillo J, Roda E, Navarro G, et al. Expression of GPR55 and either cannabinoid CB1 or $\mathrm{CB} 2$ heteroreceptor complexes in the caudate, putamen, and accumbens nuclei of control, parkinsonian, and dyskinetic nonhuman primates. Brain Struct Funct [Internet]. 2020 Sep 1 [cited 2020 Oct 28];225(7):2153-64. Available from: https://pubmed. ncbi.nlm.nih.gov/32691218/

67. Tebano MT, Martire A, Popoli P. Adenosine A2A-cannabinoid $\mathrm{CB} 1$ receptor interaction: An integrative mechanism in striatal glutamatergic neurotransmission [Internet]. Vol. 1476, Brain Research. Brain Res; 2012 [cited 2020 Sep 24]. p. 108-18. Available from: https://pubmed.ncbi.nlm.nih.gov/22565012/

68. Ferré S, Agnati LF, Ciruela F, Lluis C, Woods AS, Fuxe K, et al. Neurotransmitter receptor heteromers and their integrative role in "local modules": The striatal spine module. Brain Res Rev [Internet]. 2007 Aug [cited 2017 Dec 27];55(1):55-67. Available from: http://www.ncbi.nlm.nih.gov/pubmed/17408563

69. Ferré S, Ciruela F, Quiroz C, Luján R, Popoli P, Cunha RARA, et al. Adenosine receptor heteromers and their integrative role in striatal function. ScientificWorldJournal [Internet]. 2007 Jan 2 [cited 2016 Feb 15];7(SUPPL. 2):74-85. Available from: https:// pubmed.ncbi.nlm.nih.gov/17982579/

70. Franco R, Lluis C, Canela EI, Mallol J, Agnati L, Casadó V, et al. Receptor-receptor interactions involving adenosine A1 or dopamine D1 receptors and accessory proteins. J Neural Transm [Internet]. 2007 Jan 9 [cited 2018 Dec 30];114(1):93-104. Available from: http://www.ncbi.nlm.nih.gov/pubmed/17024327

71. Martínez-Pinilla E, Rodríguez-Pérez AII, Navarro G, Aguinaga D, Moreno E, Lanciego JLL, et al. Dopamine D2 and angiotensin II type 1 receptors form functional heteromers in rat striatum. Biochem Pharmacol [Internet]. 2015 Jul 15 [cited 2015 Dec 6];96(2):131-42. Available from: http://linkinghub.elsevier. com/retrieve/pii/S000629521500252X

72. Villar-Cheda B, Valenzuela R, Rodriguez-Perez AI, Guerra MJ, Labandeira-Garcia JL. Aging-related changes in the nigral angiotensin system enhances proinflammatory and pro-oxidative markers and 6-OHDA-induced dopaminergic degeneration. Neurobiol Aging [Internet]. 2012 Jan [cited 2019 Sep 1];33(1): 204.e1-11. Available from: https://linkinghub.elsevier.com/ retrieve/pii/S0197458010003544

73. Arnold AC, Gallagher PE, Diz DI. Brain renin-angiotensin system in the nexus of hypertension and aging. Vol. 36, Hypertension Research. Hypertens Res; 2013. p. 5-13.

74. Oertel WH. Parkinson's disease: epidemiology, (differential) diagnosis, therapy, relation to dementia. Arzneimittelforschung [Internet]. 1995 Mar [cited 2020 Jun 7];45(3A):386-9. Available from: http://www.ncbi.nlm.nih.gov/pubmed/7763330

75. Rocca W. Frequency, distribution, and risk factors for Alzheimer's disease. Nurs Clin North Am [Internet]. 1994 [cited 2020 Jun 7];29(1):101-11. Available from: https://europepmc.org/ abstract/med $/ 8121814$

76. Hornykiewicz O. The discovery of dopamine deficiency in the parkinsonian brain. J Neural Transm Suppl [Internet]. 2006;70:9-15. Available from: http://www.ncbi.nlm.nih.gov/pubmed/17017502

77. Tang D, Comish P, Kang R. The hallmarks of COVID-19 disease. PLoS Pathog [Internet]. 2020 [cited 2020 Jun 7];16(5):e1008536. Available from: http://www.ncbi.nlm.nih.gov/pubmed/32442210
78. Lyngsø C, Erikstrup N, Hansen JL. Functional interactions between 7TM receptors in the Renin-Angiotensin System-Dimerization or crosstalk? Vol. 302, Molecular and Cellular Endocrinology. 2009. p. 203-12.

79. Ferrão FM, Lara LS, Axelband F, Dias J, Carmona AK, Reis RI, et al. Exposure of luminal membranes of LLC-PK ${ }_{1}$ cells to ANG II induces dimerization of $\mathrm{AT}_{1} / \mathrm{AT}_{2}$ receptors to activate SERCA and to promote $\mathrm{Ca}^{2+}$ mobilization. Am J Physiol Physiol [Internet]. 2012 Apr 1 [cited 2019 Aug 30];302(7):F875-83. Available from: http://www.ncbi.nlm.nih.gov/pubmed/22218590

80. Franco R, Aguinaga D, Jiménez J, Lillo J, Martínez-Pinilla E, Navarro G. Biased receptor functionality versus biased agonism in G-protein-coupled receptors. Biomol Concepts [Internet]. 2018 Dec 26 [cited 2019 Jul 26];9(1):143-54. Available from: http:// www.ncbi.nlm.nih.gov/pubmed/30864350

81. Franco R, Casadó V, Cortés A, Ferrada C, Mallol J, Woods A, et al Basic concepts in G-protein-coupled receptor homo- and heterodimerization. ScientificWorldJournal. 2007;7(SUPPL. 2).

82. Labandeira-Garcia J, Rodríguez-Perez A, Garrido-Gil P, Rodriguez-Pallares J, Lanciego J, Guerra M. Brain reninangiotensin system and microglial polarization: Implications for aging and neurodegeneration. Front Aging Neurosci [Internet]. 2017 May 3 [cited 2019 Oct 4];9(MAY):129. Available from: http://www.ncbi.nlm.nih.gov/pubmed/28515690

83. Rodriguez-Perez AI, Sucunza D, Pedrosa MA, Garrido-Gil P, Kulisevsky J, Lanciego JL, et al. Angiotensin Type 1 Receptor Antagonists Protect Against Alpha-Synuclein-Induced Neuroinflammation and Dopaminergic Neuron Death. Neurotherapeutics [Internet]. 2018 Oct 9 [cited 2019 Sep 1];15(4):1063-81. Available from: http://www.ncbi.nlm.nih.gov/ pubmed/29987762

84. Rodriguez-Pallares J, Rey P, Parga JA, Muñoz A, Guerra MJ, Labandeira-Garcia JL. Brain angiotensin enhances dopaminergic cell death via microglial activation and NADPH-derived ROS. Neurobiol Dis [Internet]. 2008 Jul [cited 2019 Oct 14];31(1):5873. Available from: https://linkinghub.elsevier.com/retrieve/pii/ S0969996108000533

85. Saavedra JM. Beneficial effects of Angiotensin II receptor blockers in brain disorders. Vol. 125, Pharmacological Research. Academic Press; 2017. p. 91-103.

86. Pelisch N, Hosomi N, Ueno M, Masugata H, Murao K, Hitomi H, et al. Systemic candesartan reduces brain angiotensin II via downregulation of brain renin-angiotensin system. Hypertens Res [Internet]. 2010 Feb 27 [cited 2020 Jul 6];33(2):161-4. Available from: www.nature.com/hr

87. Foulquier S, Caolo V, Swennen G, Milanova I, Reinhold S, Recarti $\mathrm{C}$, et al. The role of receptor MAS in microglia-driven retinal vascular development. Angiogenesis [Internet]. 2019 Nov 1 [cited 2020 Oct 23];22(4):481-9. Available from: https://pubmed.ncbi. nlm.nih.gov/31240418/

88. Deshotels MR, Xia H, Sriramula S, Lazartigues E, Filipeanu CM. Angiotensin II mediates angiotensin converting enzyme type 2 internalization and degradation through an Angiotensin II type I receptordependent mechanism. Hypertension. 2014;64(6):1368-75.

89. Ferrada C, Moreno E, Casadó V, Bongers G, Cortés A, Mallol J, et al. Marked changes in signal transduction upon heteromerization of dopamine D1 and histamine $\mathrm{H} 3$ receptors. Br J Pharmacol [Internet]. 2009 May 8 [cited 2016 May 16];157(1):64-75. Available from: http://www.ncbi.nlm.nih.gov/pubmed/19413572

Publisher's Note Springer Nature remains neutral with regard to jurisdictional claims in published maps and institutional affiliations. 